
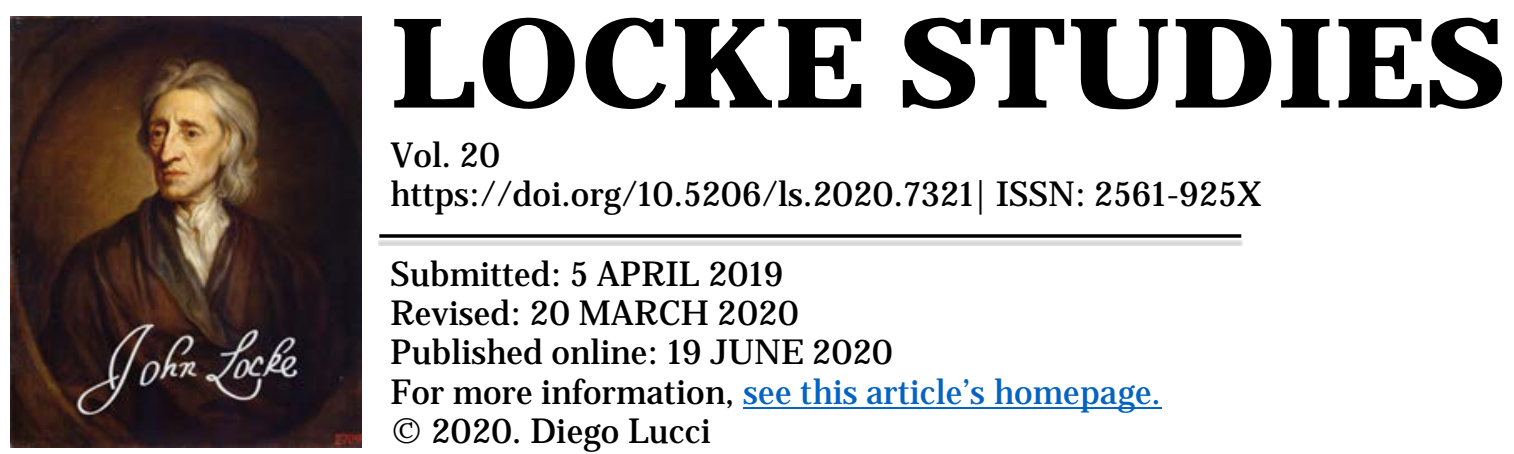

Vol. 20

https:// doi.org/ 10.5206/ls.2020.7321| ISSN: 2561-925X

Submitted: 5 APRIL 2019

Revised: 20 MARCH 2020

Published online: 19 J UNE 2020

For more information, see this article's homepage.

(C) 2020. Diego Lucci

\title{
Reconciling Locke's Consciousness-Based Theory of Personal Identity and His Soteriology
}

\author{
DIEGO LUCCI \\ (AMERICAN UNIVERSITY IN BULGARIA AND UNIVERSITY OF HAMBURG)
}

Abstract:

This article maintains that Locke's consciousness-based theory of personal identity, which Locke expounded in book 2, chapter 27 of the second edition of An Essay concerning Human Understanding (1694), perfectly fits with his views on the resurrection of the dead, the Last Judgment, and salvation. The compatibility of Locke's theory of personal identity with his soteriology has been questioned by Udo Thiel and Galen Strawson. These two authors have claimed that Locke's emphasis on repentance, which he described as necessary to salvation in The Reasonableness of Christianity (1695), clashes with his notion of punishment as annexed to personality and, hence, to consciousness. Pace Thiel and Strawson, I argue that Locke's theory of personal identity is compatible with his concept of repentance. To this purpose, I first explain Locke's views on the soul's death and the resurrection of the dead on Judgment Day, when, according to Locke, we will all be raised from death by divine miracle, but only the repentant faithful will be admitted to eternal bliss while the wicked will be annihilated. Locke's mortalism, along with his agnosticism on the ontological constitution of thinking substances or souls, played a role in his formulation of a non-substantialist account of personal identity, because it denied the temporal continuity of the soul between physical death and resurrection and it rejected the resurrection of the same body. I then analyze Locke's consciousness-based theory of personal identity, with a focus on the implications of this theory regarding moral accountability. Finally, I turn my attention to Thiel's and Strawson's considerations about Locke's views on consciousness and repentance. To prove that Locke's views on salvation are consistent with his theory of personal identity, I clarify Locke's soteriology, which describes not only repentance, but also obedience, faith, and the conscientious study of Scripture as necessary to salvation.

Keywords: Arminianism, consciousness, J ohn Locke, Last J udgment, mortalism, personal identity, repentance, resurrection, salvation, Socinianism

Locke Studies is published by The John Locke Society.

This is an open access article published under the terms of the Creative Commons AttributionNonCommercial-ShareAlike 4.0 International license, which permits use, distribution and reproduction in any medium, provided the original work is properly cited and shared under the original license. 


\section{Introduction}

Book 2, chapter 27 of An Essay concerning Human Understanding - a chapter that Locke added to the second edition of the Essay in 1694-argues that consciousness alone makes personal identity. ${ }^{1}$ It follows that one's consciousness of their past thoughts and actions will be taken into account on the Last J udgment. In this regard, Udo Thiel has maintained that Locke's consciousness-based theory of personal identity clashes with his emphasis on repentance, which Locke described as necessary to salvation in The Reasonableness of Christianity (1695). ${ }^{2}$ In his book The Early Modern Subject (2011), Thiel observes that Essay II.xxvii.22 states that "punishment [is] annexed to personality [i.e., personal identity], and personality to consciousness." 3 Therefore, according to Thiel, one's consciousness of their past misdeeds still makes them subject to punishment on Judgment Day, regardless of their repentance, thus making their salvation impossible. 4 Furthermore, in the monograph Locke on Personal Identity, published in the samemonth and year as Thiel's above-mentioned book (September 2011), Galen Strawson grapples with the question whether Locke's account of personal identity leaves room for repentance, and he explores several options for accommodating repentance. ${ }^{5}$ Nevertheless, none of the options considered by Strawson proves convincing enoughand, indeed, he does not endorse any of these options resolutely-because Strawson does not support the solutions he considers with a thorough analysis of Locke's views on salvation in the Reasonableness. In fact, in their otherwise excellent books, both Thiel and Strawson abstract Locke's notion of repentance from the context of his soteriology and pay scarce attention to the complexity of Locke's theory of salvation, which encompasses more than merely a focus on repentance. Pace Thiel and Strawson, I believe that Locke's consciousness-based theory of personal identity and his views on repentance can be reconciled if we examine Locke's soteriology in detail. To Locke, salvation and damnation are actually not only a matter of considering a person's past misdeeds and consciousness thereof. Repentance, too, will be taken into account on the Last J udgment. However, according to Locke, repentance alone does not qualify a sinner for salvation, because faith, repentance, and obedience (the three fundamentals of Christianity), along with the conscientious study of Scripture, all play a role in the pursuit of salvation.

1 J ohn Locke, An Essay concerning Human Understanding, edited by Peter H. Nidditch (Oxford: Clarendon Press, 1975), II.xxvii, 328-48.

2 J ohn Locke, The Reasonableness of Christianity, as Delivered in the Scriptures, edited by J ohn C. Higgins-Biddle (Oxford: Clarendon Press, 1999), 111- 12.

3 Locke, Essay, II.xxvii.22, 344.

4 Udo Thiel, The Early Modern Subject: Self-Consciousness and Personal Identity from Descartes to Hume (Oxford: Oxford University Press, 2011), 143.

5 Galen Strawson, Locke on Personal Identity: Consciousness and Concernment, 2nd revised edition (Princeton: Princeton University Press, 2014), 139- 49. 
The purpose of this article is to demonstrate that Locke's consciousness-based theory of personal identity is consistent with his notion of repentance and, generally, with his soteriology. In fact, Locke's consciousness-based theory of personal identity was inspired not only by his intention to clarify concepts like identity and diversity, but also by the need to provide an account of personal identity, and hence of moral accountability, consistent with his views on the resurrection of the dead, divine judgment, and otherworldly reward and punishment. Therefore, in this article I first explain Locke's views on the soul's death and the resurrection of the dead on J udgment Day. A brief but detailed explanation of Locke's mortalist ideas is essential to appreciate his conception of the afterlife and the Last J udgment, when, according to Locke, we will all be raised from death by divine miracle, but only the righteous and repentant faithful will be admitted to eternal bliss while the wicked will be annihilated. Moreover, Locke's mortalism, along with his agnosticism on substance, which entailed agnosticism on the ontological constitution of thinking substances or souls, played a role in his formulation of a non-substantialist account of personal identity, because it denied the temporal continuity of the soul between physical death and resurrection and it rejected theresurrection of the same body. I then provide a concise analysis of Locke's consciousness-based theory of personal identity, with a focus on the implications of this theory concerning, in particular, moral accountability, since the question examined in this article is relevant to divine judgment of one's deeds. Finally, I turn my attention to Thiel's and Strawson's aforesaid considerations about Locke's views on consciousness and repentance. Unlike Thiel and Strawson, I argue for the compatibility of Locke's theory of personal identity with his emphasis on repentance as necessary, albeit not sufficient, to salvation. To substantiate my thesis, I provide an examination of Locke's theory of salvation, which he expounded in The Reasonableness of Christianity.

Before proceeding with my analysis, I need to give some preliminary clarifications, starting with a brief account of the impact that two heterodox theological currentsSocinianism and Arminianism - had on Locke's religion, since I often refer to his Socinian and Arminian influences when elucidating his religious ideas. Socinianism is an antiTrinitarian and anti-Calvinist theological tradition, named after the sixteenth-century Italian theologian Faustus Socinus, who lived in Poland from the late 1570s to his death in 1604. When in Poland, he settled among the mostly Polish and German members of the anti-Trinitarian Minor Reformed Church, also called "Polish Brethren." Upon Socinus's death, second and third-generation Socinians, including, among others, J ohann Crell, J onas Schlichting, and the editors of the final, 1680 Latin edition of the Socinian summa known as Racovian Catechism, further refined Socinian theology, in some cases under the influence of Dutch Arminianism. ${ }^{6}$ Socinian ideas also spread in England from

6 The Racovian Catechism was originally published in Polish by the Socinians' press in Rakówin 1605. Its first Latin translation appeared in Raków in 1609. Between the seventeenth and the nineteenth century, this book received several editions in different languages. The 1680 Latin Catechism is considered the final edition of this work prepared by Socinians-mainly by Socinus's grandson Andrzej Wiszowaty (who died two years before its publication in Amsterdam) and great-grandson Benedykt Wiszowaty. The editors of the 1680 edition drew on various seventeenth-century Socinian authors in revising the text. 
the Civil War and Interregnum period on, thus promoting the development of English Unitarianism and provoking a harsh Trinitarian controversy in the late seventeenth century. Locke's religious views overlap with Socinianism in several respects; and this is not an accident, given that he had excellent knowledge of Socinian thought: he owned many Socinian and Unitarian works, and he mentioned Socinian as well as Unitarian texts and authors in various manuscripts. Many elements of Locke's religious thought denote his Socinian influences. As we will see below, his views on the soul's death and the resurrection of the dead were identical to the mortalist ideas held by seventeenth-century Socinians like Crell, Schlichting, and the editors of the final Racovian Catechism. Moreover, he followed Socinus and his disciples in characterizing "person" as a forensic term. Furthermore, he adopted Socinus's proof of scriptural authority, which highlighted the fulfillment of Old Testament messianic prophecies in the New Testament, the excellence of Christ's precepts, and Christ's miracles. Locke's stress on the fundamentals of Christianity with his subsequent irenicism, his moralist soteriology, his dislike of original sin, satisfaction, and predestination, and his emphasis on the "advantages of Christ's coming," particularly on the assurance of otherworldly rewards and sanctions and of God's mercy, also echo Socinian soteriology. ${ }^{7}$ Nevertheless, Locke was not a Socinian proper, since he never expressly denied belief in the Trinity. Moreover, while the Socinians argued that the revealed moral law had partly invalidated and thus replaced the Law of Nature, Locke regarded the Law of Nature as divinely given and hence universally and eternally valid. He actually disassociated himself from Socinianism and described his interpretation of Christianity as merely based on Scripture during his dispute with the Calvinistic divine J ohn Edwards, who criticized the Reasonableness as a Socinian book. ${ }^{8}$

Another heterodox theological current that influenced Locke's religious thought and particularly his soteriology was Arminianism, named after the sixteenth and early seventeenth-century anti-Calvinist Dutch theologian J acobus Arminius. Arminius and his followers stressed the possibility for human beings to embrace or resist God's grace, which they considered as assisting grace. Therefore, they upheld a moralist soteriology, maintaining that salvation was conditioned by both graciously-enabled faith and moral works. Shortly after Arminius's death, his disciples published the main tenets of Arminian theology in the "Five Articles of Remonstrance" (1610) and were subsequently known as Remonstrants. Arminianism developed particularly in the Netherlands, thanks to scholars such as Hugo Grotius, Simon Episcopius, Etienne de Courcelles, and Locke's friends Philipp van Limborch and J ean Le Clerc. However, this theological current also had a significant impact in England, mainly among the members of the Great Tew Circle and other anti-Calvinist theologians between the 1630s and the 1650s and, after the

7 On the similarities between Locke and the Socinian tradition, see, especially, J ohn Marshall, "Locke, Socinianism, 'Socinianism,' and Unitarianism," in English Philosophy in the Age of Locke, edited by M. A. Stewart (Oxford: Clarendon Press, 2000), 111- 82.

8 For Locke's disassociation from Socinianism, see, in particular, J ohn Locke, "A Second Vindication of the Reasonableness of Christianity," in Vindications of the Reasonableness of Christianity, edited by Victor Nuovo (Oxford: Clarendon Press, 2012), 126. 
Restoration, among the "latitude-men." Locke had good knowledge of Arminian theology, as he owned and read various works by Dutch Remonstrants and Arminian-influenced English writers, including, among others, William Chillingworth, J eremy Taylor, and his friend, Archbishop John Tillotson. Locke's familiarity with Arminian thought is also demonstrated by his religious writings, which denote many points in common with Arminianism, such as a moralist soteriology, a view of grace as assisting grace, an emphasis on the fundamentals of Christianity, a markedly irenic attitude, and a position on atonement very close to Grotius's and Limborch's governmental theory. Nevertheless, Locke cannot be considered as an Arminian proper, because his mortalism, his explicit denial of original sin, and his obstinate public silence on the Trinitarian doctrine (even after some critics asked him to clarify his position on the Trinity) place his religious thought outside of the Arminian theological tradition. In fact, even when considering different authors and traditions in his theological writings, Locke always made sure that his conclusions were in line with, and indeed grounded in, the Scriptures. Briefly, Locke's religion, although explained unsystematically in his public as well as private writings, is an original, Scripture-based, internally coherent version of Protestant Christianity which, "on the theological map of his day," can be considered as being "somewhere between Socinianism and Arminianism."9

Concerning Locke's theory of personal identity, it is worth noting that several aspects of this theory are still issues for debate, due to Locke's succinctness or, in some cases, ambiguity on various matters. There is actually no consensus among Locke experts concerning matters like the ontological status of Lockean persons (which have been variously interpreted as modes or substances), the ontological constitution of the unifying component of consciousness, the role of appropriation in making personal identity, and whether the nature of thinking substances is simply unknown or unknowable to us. Given that a discussion of these issues is beyond the scope of my point here, I do not concentrate on these controversial aspects of his theory. ${ }^{10}$ I rather focus on the compatibility of Locke's theory of personal identity with his theological, and particularly soteriological, reflections.

Finally, it is true that An Essay concerning Human Understanding is a philosophical work, although one tending toward theological investigation in that it also concentrates on God's existence as a creator and legislator, ${ }^{11}$ the necessity of revelation as an

9 Arthur W. Wainwright, introduction to A Paraphrase and Notes on the Epistles of St Paul to the Galatians, 1 and 2 Corinthians, Romans, Ephesians, by J ohn Locke, edited by Arthur W. Wainwright, 2 vols. (Oxford: Clarendon Press, 1987), 1:58.

10 For a concise but excellent account of the still debated issues surrounding Locke's theory of personal identity, see J essica Gordon-Roth, "Locke on Personal Identity," in Stanford Encyclopedia of Philosophy, published February 11, 2019, https:// plato.stanford.edu/ entries/locke-personal-identity/.

11 Locke, Essay, I.iv.9, 89; II.xxiii.12, 302- 3; IV.x.1- 6, 619-21. In these sections of the Essay, Locke employed the argument from design and the anthropological argument to prove God's existence. 
"enlargement" of natural reason, 12 and the need to believe in things above reason revealed in Scripture. ${ }^{13}$ Conversely, The Reasonableness of Christianity is a book of biblical theology concerning primarily the question of justification-namely, what it is that "justifies" human beings who have sinned and, thus, enables their salvation. However, I think that the Reasonableness is in continuity with the Essay, particularly with Locke's moral inquiry in this work. In this respect, I agree with Victor Nuovo, who has commented:

Locke concluded the Essay by declaring that in the light of the human situation in the world and the capacities and limitations of human knowledge, morality is the proper business of mankind and that to be efficacious it must be joined to religion. The Reasonableness was intended to accomplish this. This turning toward religion, however, does not require the abandonment of natural reason, rather its enlargement through revelation, not by endowing it with transcendent capacities, but by showing the reasonableness of extending belief to matters beyond the capacity of reason and experience to discover. ${ }^{14}$

Locke acknowledged the limited scope of human knowledge in ethics and theology, although he thought that ethics and theology had different epistemological statuses, since he considered morality demonstrable (at least in principle) while he regarded most theological knowledge as falling within the scope of probability-with the significant exception of our knowledge of God's existence, which to Locke is demonstrative and implies an understanding that we have duties toward our creator. Locke's concerns with morality and religion, and with the limits of human knowledge in these fields of inquiry, permeated his philosophical production since at least the early 1660s and informed his mature works, including the Essay. Thus, the Reasonableness presents a continuation of Locke's struggle to establish morality on solid grounds, although in this book heabstained from attempting to formulate the epistemological foundations of morality. He concentrated, instead, on promoting the practice of morality and the development of moral character on the basis of what he took to be a coherent, convincing, Scripture-based theological ethics.

\section{Death and Resurrection}

Concerning the afterlife and the Last J udgment, Locke expressed mortalist, particularly thnetopsychist, views. Thnetopsychism, which is the doctrine that the soul dies with the body and will then be raised again by divine miracle for the Last J udgment, differs from

12 Locke, Essay, IV.xix.4, 698.

13 Locke, Essay, IV.xvii.23, 687; IV.xviii.6- 10, 693-96.

14 Victor Nuovo, J ohn Locke: The Philosopher as Christian Virtuoso (Oxford: Oxford University Press, 2017), 216. 
the other two major versions of Christian mortalism-psychopannychism, which maintains that the soul sleeps until its awakening on J udgment Day, and annihilationism, which considers the soul absolutely and permanently mortal. Mortalist ideas first emerged among Christians, especially in the East, in the second century, and were denounced as heretical in the early Middle Ages. By the late sixteenth century, mortalism, mainly in its thnetopsychist version, had reemerged and had become a minor but influential heresy in Protestant Europe. Mortalist ideas were actually compatible with some crucial points of Protestant doctrine, such as the rejection of Purgatory and the conviction that the soul's destiny in the afterlife depends exclusively on God - and not also on some ecclesiastical or other human authorities or intercessions. ${ }^{15}$ Therefore, various radical Protestants, mostly anti-Trinitarians like Michael Servetus, Simon Budny, Faustus Socinus, John Biddle, and John Milton, approved of thnetopsychism, whereas all Magisterial Reformers rejected thnetopsychist views. While Luther held psychopannychist ideas, Calvin rejected any sort of mortalism. In England, the FortyTwo Articles of the Church of England (1553) condemned both soul-sleep and soul-death. Church of England members in the early modern era actually held, almost always, to natural immortality. They believed that there is an intermediate state between physical death and the resurrection of the dead. In this intermediate state, the soul is conscious and exists in happiness or misery until J udgment Day, when it will be reunited to the body and receive its final reward. However, the Thirty-Nine Articles of 1563 contained no explicit censure of mortalist ideas. ${ }^{16}$ During the Civil Wars and Interregnum, thnetopsychist views appealed to heterodox intellectuals like the physician Thomas Browne, the Leveller pamphleteer Richard Overton, Thomas Hobbes, and the aforementioned Biddle and Milton, as well as less sophisticated sectarians from marginal groups like the Ranters and the Familists. The spread of mortalist ideas in midseventeenth-century England was promoted by both the development of the natural sciences, especially of medicine and anatomy, and Puritan Biblicism. ${ }^{17}$

Locke's father was familiar with mortalist theories, since he read Overton's Mans Mortalitie (1644). ${ }^{18}$ However, Locke's mortalist ideas are identical to some Socinian authors' views on the matter, although not to Socinus's own position. Socinus rejected the idea that the human soul was naturally immortal. Though, he did not believe in the resurrection of the wicked to punishment. He thought that only the righteous will be raised to eternal salvation. To Socinus, the punishment of the wicked is mere annihilation at death. A slightly different version of thnetopsychism eventually came to prevail among

15 Norman T. Burns, Christian Mortalism from Tyndale to Milton (Cambridge: Harvard University Press, 1972), 9, 51; Bryan W. Ball, The Soul Sleepers: Christian Mortalism from Wycliffe to Priestley (Cambridge, UK: J ames Clarke \& Co, 2008), 28, 44-49; Richard Sugg, The Smoke of the Soul: Medicine, Physiology and Religion in Early Modern England (Basingstoke: Palgrave Macmillan, 2013), 211.

16 Ball, Soul Sleepers, 59- 61.

17 Burns, Christian Mortalism, 74- 87; Sugg, Smoke of the Soul, 215- 23.

18 Roger Woolhouse, Locke: A Biography (Cambridge: Cambridge University Press, 2007), 7. 
Socinians in the seventeenth century. Socinian writers like Johann Crell, Jonas Schlichting, and the editors of the final Racovian Catechism believed, unlike Socinus, in a general resurrection of both the righteous and the wicked, followed by the enjoyment of eternal beatitude by therighteous and the final annihilation, after unspeakable albeit brief sufferings, of the wicked. ${ }^{19}$ Locke shared these Socinians' views on the destiny of the soul in the afterlife. He believed that, upon Christ's Second Coming, a general resurrection of the dead will take place and will be followed by the Last J udgment. Whereas the righteous will be admitted to enjoy eternal bliss in heaven, the wicked will be resurrected for only a short time in order to suffer a brief but terrible torment and die a second, final death. According to Locke, the resurrection of the righteous to eternal life is a miraculous event, while annihilation upon resurrection is the logical punishment of the wicked. ${ }^{20}$

The most comprehensive and systematic account of Locke's views on the matter is in a manuscript, "Resurrectio et quae sequuntur," which he wrote, most probably, in 1699, at the time when he was working on A Paraphrase and Notes on the Epistles of St Paul. ${ }^{21}$ The views he expressed in this manuscript actually inform his interpretation of Paul's epistles on this matter in the Paraphrase, since "Resurrectio et quae sequuntur" is largely based on Paul's stance on the resurrection of the dead-mainly, but not exclusively, on what Paul wrote on this matter in 1 Cor. $15 .{ }^{22}$ In this manuscript, Locke maintained that "all men by the benefit of Christ shall be restored to life" and that the Second Coming of Christ will be followed by the resurrection of "those that are his" and, afterwards, by "the

19 For the Socinians' mortalist views, see George H. Williams, ed., The Polish Brethren: Documentation of the History and Thought of Unitarianism in the Polish-Lithuanian Commonwealth and in the Diaspora 1601- 1685, 2 vols. (Missoula: Scholars Press, 1980), 1:106- 7, 1:202-4, 1:237, 1:326, 2:407, 2:416, and 2:686.

20 On Locke's mortalism and its connection to his theory of personal identity and to the context of mortalism in early modern Europe and England, see: Wainwright, introduction to Paraphrase, 51-56; Philip C. Almond, Heaven and Hell in Enlightenment England (Cambridge: Cambridge University Press, 1994), 129- 30, 140 - 43; J ohn Marshall, J ohn Locke: Resistance, Religion and Responsibility (Cambridge: Cambridge University Press, 1994), 399-401; Marshall, "Locke, Socinianism," 159- 61; J ohn C. HigginsBiddle, introduction to Reasonableness by Locke, cxxi- cxxii; Stephen D. Snobelen, "Socinianism, Heresy and J ohn Locke's Reasonableness of Christianity," Enlightenment and Dissent 20 (2001): 114-20; Ball, Soul Sleepers, 120- 26; Nicholas J olley, Locke's Touchy Subjects: Materialism and Immortality (Oxford: Oxford University Press, 2015), 99- 115. Locke's mortalist ideas, which emerged from the Reasonableness and other public works, caused a long and harsh debate, which involved, among others, Edward Stillingfleet and Gottfried Wilhelm Leibniz.

21J ohn Locke, "Resurrectio et quae sequuntur," in J ohn Locke: Writings on Religion, edited by Victor Nuovo (Oxford: Oxford University Press, 2002), 232- 37.

22 Locke, Paraphrase, 1 Cor. 15, 1:246-56. When referring to the Bible and quoting from it in this article, I refer to the King J ames Version (KJ V), which is also the version that Locke used, as a conforming (albeit heterodox) member of the Church of England. Locke owned various copies of the Bible, including, among others, a 1648 English Bible printed by William Bentley, interleaved and annotated by Locke, and now preserved at the Bodleian Library (Locke 16.25): see J ohn Harrison and Peter Laslett, eds., The Library of J ohn Locke, 2nd edition (Oxford: Clarendon Press, 1971), item no. 309, 86. 
resurrection of the wicked," which will take place "before our Saviour delivers up the Kingdom to his father, for then is the end." He argued that the wicked "shall not live forever" because "the wages of sin is death," while "the reward of the righteous is everlasting life." Therefore, upon the resurrection of the dead, there will be "life to the just, to beleivers, to the obedient; \& death to the wicked \& unbeleivers." In this regard, Locke explained that, when Scripture threatens death as "the ultimate punishment \&last estate to which the wicked must all come," by "death" is not meant "eternal life in torment." Hecited several biblical passages in support of his point. Heclarified that, when Gal. 6:8 states that "he that soweth to his flesh shall of the flesh reap corruption; but he that soweth to the spirit shall of the spirit reap life everlasting," the terms "corruption \& life everlasting are opposed," and by corruption is meant "the dissolution \& final destruction of a thing whereby it ceases to be." Moreover, when considering "the everlasting fire threatened by our saviour to the wicked" in Mat. 18:8 and Mat. 25:41- 46, he argued that "everlasting in a true scripture sense may be said of that which endures as long as the subject it affects endures" and that, consequently, "the wicked shall die \& be extinguished at last."23

Although Locke wrote his most thorough account of his mortalist ideas in the late 1690s, various passages in The Reasonableness of Christianity and several theological manuscripts, most of which are drafts of different sections of the Reasonableness, demonstrate that he already held mortalist views, and paid attention to 1 Cor. 15, by the mid-1690s. ${ }^{24}$ Concerning human mortality, the Reasonableness states: "by Death here I can understand nothing but a ceasing to be, the losing of all actions of Life and Sense. Such a Death came on Adam, and all his Posterity by his first Disobedience in Paradise, under which Death they should have lain for ever, had it not been for the Redemption by J esus Christ."25

In the Reasonableness, Locke described resurrection and eternal lifeas made possible, following redemption by Christ, only by a divine miracle. As regards otherworldly sanctions, he maintained that "Immortality and Bliss belong to the Righteous," who will be "re-instated in an Happy Immortality," while the wicked will suffer a "second Death."26 In this respect, too, the Reasonableness anticipated the thesis of "Resurrectio et quae

23 Locke, “Resurrectio,” 232- 36.

24 Wainwright, introduction to Paraphrase, 52-53. See also Locke, Reasonableness, 7- 16, 104, 117. For Locke's manuscripts on this matter, see "On the Immortality of the Soul," in An Early Draft of Locke's Essay: Together with Excerpts from His J ournals, edited by Richard I. Aaron and J ocelyn Gibb (Oxford: Clarendon Press, 1936), 121- 23 (from Locke’s journal, 20 February 1682); “Christianitie," MS Locke c. 27, f. 101, in Reasonableness, 198- 200 (written around 1695); "Adam ante lapsum immortalis," MS Locke c. 27, f. 103, in Reasonableness, 201 (written around 1695); MS Locke c. 27, ff. 104- 111, in Reasonableness, 201- 5 (containing a list of biblical verses compiled, probably, around 1695); "Spirit, Soul, and Body," in Paraphrase, 2:675- 78 (composed in 1697 or later).

25 Locke, Reasonableness, 8-9.

26 Locke, Reasonableness, 13, 104, 117. 
sequuntur," in that it argued that, in Scripture, by "death" is meant literal terminationnot "endless torment in Hell-fire" and "Eternal Life in Misery." 27

Locke never stated expressly that the human soul is mortal, but his thesis that the righteous will need a miracle to be resurrected on Judgment Day and to enjoy eternal beatitude, while the wicked will be destroyed shortly after being revived, implicitly denies the natural immortality of the soul. Locke's view of the soul as not naturally immortal implies that there is no uninterrupted temporal continuity between the existence of a soul in this world and its existence in the afterlife upon resurrection - whether to enjoy eternal bliss or to suffer horrible torments and then be destroyed again and forever. Furthermore, Locke's agnosticism on substancein An Essay concerning Human Understanding entails that we do not know whether the soul, or thinking substance, is material or immaterial. To Locke, substance is indeed an unknown support, or "substratum," of ideas that are "conveyed in by the Senses, as they are found in exteriour things, or by reflection on [the mind's] own operations" and that cannot "subsist by themselves." 28 In this respect, Essay II.xxiii.4 states that "we have no clear, or distinct Idea of that thing we suppose a Support." 29 In regard to our own thinking, we are aware of our thoughts and we have an idea of our thinking; but we have no clear and distinct idea of the underlying entity in which our thinking takes place and of its ontological constitution-whether it is material or immaterial. ${ }^{30}$ In other words, we have no clear and distinct idea of a thinking substance or soul. Locke's ambiguity, or rather agnosticism, about the immateriality or materiality of the soul emerges not only from the Essay, but also from two manuscripts that he composed at different times. In a journal entry dated 20 February 1682, he questioned the compatibility between two attributes commonly ascribed to the soul, namely its (natural) immortality and its immateriality, since immortality would make sense only in the presence of sensibility. ${ }^{31}$ More than one decade later, in the entries on this subject in "Adversaria Theologica," he endorsed contrasting arguments with his initials, thus manifesting an ambiguous or undecided position on this issue. 32 For instance, he endorsed the following argument in favor of the view that the soul is immaterial: "We cannot conceive one material atom to think nor any Systeme of Atoms or particles to

27 Locke, Reasonableness, 7.

28 Locke, Essay, II.xxiii.1, 295.

29 Locke, Essay, II.xxiii.4, 297.

30 Locke, Essay, IV.iii.6, 539-43. See Ruth Boeker, "Locke on Personal Identity: A Response to the Problems of His Predecessors,” J ournal of the History of Philosophy 55, no. 3 (2017): 412.

31 Locke, "Immortality," 121-23.

32 J ohn Locke, "Adversaria Theologica 94," in Writings on Religion, 28- 30. In this manuscript, which presents divergent arguments concerning various theological issues, Locke signed his initials next to the arguments he endorsed. 
think." 33 But he also endorsed the following argument, which is compatible with the hypothesis of the materiality of the soul: "We can conceive noe movable substance without extension, for what is not extended is nowhere. i e is not. From this \& the opposite view we must conclude there is something in the nature of Spirits or thinking beings which we cannot conceive."34

Concerning the body in which the soul will be resurrected, Locke wrote in Essay II.xxvii.15: "we may be able without any difficulty to conceive, the same Person at the Resurrection, though in a Body not exactly in make or parts the same which he had here." 35 Locke saw the soul and the body as interdependent. For this reason, he thought that bodily death entails the death of the soul. For the same reason, he believed that the soul will need a body to sustain it upon resurrection, but this body cannot be the same, corruptible, mortal body united to the soul during its earthly life. Therefore, it will be a new, incorruptible, "spiritual" body. In the Reasonableness, referring to 1 Cor. 15:54, Locke indeed stated that our "frail Mortal Bodies" will be changed into "Spiritual Immortal Bodies at the Resurrection," and he talked of the "Resurrection of the dead," not of their bodies. ${ }^{36}$ He repeated the notion that "the saints shall then have spiritual \& immortal bodys" in "Resurrectio." 37 In this manuscript, drawing on several passages from 1Cor. 15, he clarified:

we shall all be changed in the twinkleing of an eye .... Because this corruptible thing must put on incorruption \& this mortal thing put on immortality. how? by putting off flesh \& bloud by an instantaneous change because ... Flesh \& bloud cannot inherit the kingdom of god. ... . Men alive are flesh \&bloud, the dead in the graves are but the remains of corrupted flesh \& bloud. But flesh \& bloud can not inherit the kingdom of god, neither can corruption inherit incorruption i e immortality. 38

It is worth clarifying that, when using the term "change" in this context, Locke did not mean that God will revive and modify the deceased body. He rather meant that God will provide a brand new, "spiritual" body for the saved at resurrection. In fact, in "Resurrectio", he mentioned the "putting off" of flesh and blood. Moreover, when

33 Locke, "Adversaria," 28.

34 Locke, “Adversaria," 30.

35 Locke, Essay, II.xxvii.15, 340.

36 Locke, Reasonableness, 115- 16.

37 Locke, “Resurrectio,” 232.

38 Locke, "Resurrectio," 233. It is worth noting, incidentally, that Locke, while maintaining that "corruptible" flesh and blood cannot inherit the Kingdom of God, did not consider the fact that Christ's body at resurrection still bore the wounds of crucifixion. 
replying, in the late 1690s, to Bishop Edward Stillingfleet's reaffirmation of the resurrection of the body, he expressly denied that "the resurrection of the same body ... is an article of the Christian faith." 39 As to the bodies of the wicked, however, he abstained from drawing any conclusion, given the lack of scriptural references to this subject: "Nor doe I remember any mention of the change of the bodys where the resurrection of the wicked can be supposed to be comprehended. ... But of the change of their bodys of their being made spiritual or of their putting on incorruption or immortality I doe not remember any thing said. They shall be raised is said over \&over, But how they are raised or with what bodys they shall come the Scripture as far as I have observed is perfectly silent." 40

Finally, whereas in the first three editions of An Essay concerning Human Understanding Locke had referred to the resurrection of "bodies," he repeatedly spoke of the "resurrection of the dead," not of their bodies, in the fourth edition of the Essay, published in 1700, and in the Paraphrase, particularly when paraphrasing and commenting on 1 Cor. 15:42- 50. ${ }^{41}$ Locke's paraphrase and notes on 1 Cor. 15:42 actually present the same comments expressed in "Resurrectio" about "flesh and blood," and "corruption," which cannot inherit immortality. 42 In the Paraphrase, Locke also reasserted his agnosticism on the bodies of the wicked at resurrection, given Paul's silence on this subject, and he reaffirmed the view that the saved "shall have from Christ the second Adam spiritual bodys," which will enable them to "subsist perpetually" in a "state of immutable incorruptibility." 43

\section{Personal Identity}

Locke's mortalism and agnosticism on substance have heterodox implications concerning personal identity. Locke's theory that the human soul perishes with the body and will need a divine miracle to be resurrected on J udgment Day, his idea that our "frail Mortal Bodies" will be changed into "Spiritual Immortal Bodies at the Resurrection," and his view that we do not have a clear and distinct idea of a thinking substance or soul and of its ontological constitution make it difficult, or even impossible, to argue that personal

39 J ohn Locke, Reply to the Right Reverend the Lord Bishop of Worcester's Answer to His Second Letter, in The Works of J ohn Locke, 9 vols., 12th ed. (London, 1824), 3:303.

40 Locke, “Resurrectio,” 237.

41 Locke, Essay, IV.iii.29, 559-60; IV.xvii.23, 687; IV.xviii.7, 694; Locke, Paraphrase, 1 Cor. 15:4250, 1:253- 55 .

42 Locke, Paraphrase, 1 Cor. 15:42, 1:253.

43 Locke, Paraphrase, 1 Cor. 15:44, 1:254, and 1 Cor. 15:50, 1:255. On Locke's views on the body at resurrection, see Luisa Simonutti, "Locke's Biblical Hermeneutics on Bodily Resurrection," in Locke and Biblical Hermeneutics: Conscience and Scripture, edited by Luisa Simonutti (Cham: Springer, 2019), 5574. 
identity is in the soul, or in the body, or in a union of body and soul. Locke was aware of this significant problem and its moral implications. In fact, personal identity entails moral accountability, which is not only taken into account in matters relevant to human justice, but will also be considered on the Last Judgment. Given also Locke's emphasis on individual responsibility concerning matters relevant to salvation, he needed to provide an account of personal identity consistent with both his mortalism and his way of ideas.

Locke decided to expound his theory of personal identity when, in a letter dated 2 March 1693, his friend William Molyneux encouraged him to clarify his position on the principium individuationis (principle of individuation). ${ }^{44}$ The principium individuationis, as Udo Thiel has put it, defines "what it is that makes an individual the individual it is and distinguishes it from all other individuals of the same kind." 45 Locke concentrated on this issue in the second edition of An Essay concerning Human Understanding, published in 1694, precisely in book 2, chapter 27, "Of Identity and Diversity." In this chapter, Locke paid great attention to the principle of individuation of persons and to personal identity, delineating a theory that significantly diverges from the traditional Christian understanding of these concepts.

Christian thought since the sixth century has largely shared Boethius's definition of "person" as an "individual substance of a rational nature." In the early modern era, even the Socinians and other anti-Trinitarians adopted this definition of "person." They argued that the Trinitarian dogma, which maintains the consubstantiality of the three divine persons, was illogical, besides being unscriptural. In their opinion, given Boethius's equation of person with an individual substance, three persons cannot share one substance. The Socinians' and other anti-Trinitarians' use of the Boethian theory of personhood entails a substantialist view of the divine persons consistent with a notion of human person based on Boethius's definition. Nevertheless, in the traditional Christian account of personhood, adopted with different purposes by both Trinitarian and antiTrinitarian theologians in the early modern period, the concept of human person assumes the union of body and soul, both described in substantialist terms. According to this notion of individuation, human individuality is constituted by the particular union of body and soul, which is a particular subsistence, or manner of subsistence, of human nature. Edward Stillingfleet's points on this subject, during his dispute with Locke, in the late 1690s, about the anti-Trinitarian potential of the latter's way of ideas, exemplify this position. Claiming that Locke's way of ideas, with its agnosticism on substance, was incompatible with the traditional, substantialist notion of person underlying the Trinitarian dogma, Stillingfleet reaffirmed that a "person" is a "compleat intelligent Substance, with a peculiar manner of Subsistence." 46 He added that "we take Person with Relation to Soul and Body united together. And so, the Identity of Person must take in

44 William Molyneux to Locke, 2 March 1693, in The Correspondence of J ohn Locke, edited by E. S. de Beer, 8 vols. (Oxford: Clarendon Press, 1976-1989), no. 1609, 4:647- 52.

45 Udo Thiel, "The Trinity and Human Personal Identity," in English Philosophy, ed. Stewart, 217- 18.

46 Edward Stillingfleet, A Discourse in Vindication of the Doctrine of the Trinity (London, 1697), 261. 
both, not only here, but at the Resurrection." 47 Stillingfleet's claim that Locke had departed from the traditional, substantialist understanding of person was not ill grounded. In fact, when Locke embarked on offering a solution to the problem of individuation and, thus, on formulating a theory of personal identity in the 1694 edition of the Essay, he provided a non-substantialist account of personal identity and developed, instead, a consciousness-based theory of personal identity.

Essay II.xxvii makes a distinction between the principium individuationis as an ontological notion and identity as an epistemic notion. To Locke, the principium individuationis is "Existence it self, which determines a Being of any sort to a particular time and place incommunicable to two Beings of the same kind." 48 Identity is a more complex concept. Udo Thiel has accurately explained Locke's views on this matter: "our concepts determine what is required for the identity of objects over time. . . . According to Locke, then, what constitutes the identity of a being through time is the continued fulfilment of those requirements which are specified by that abstract idea under which we consider the being: there can be no satisfactory treatment of identity through time independently of our abstract ideas of those things whose identity is in question." 49 This means that, as Locke himself acknowledged, different people could determine different requirements for the identity of objects over time. Essay II.xxvii.29 considers the case of the identity of "man":

For supposing a rational Spirit be the Idea of a Man, 'tis easie to know, what is the same Man, viz. the same Spirit, whether separate or in a Body will be the same Man. Supposing a rational Spirit vitally united to a Body of a certain conformation of Parts to make a Man, whilst that rational Spirit, with that vital conformation of Parts, though continued in a fleeting successive Body, remains, it will be the same Man. But if to any one the Idea of a Man be, but the vital union of Parts in a certain shape; as long as that vital union and shape remains, in a concrete no otherwise the same, but by a continued succession of fleeting Particles, it will be the same Man. For whatever be the composition whereof the complex Idea is made, whenever Existence makes it one particular thing under any denomination, the same Existence continued, preserves it the same individual under the same denomination. 50

47 Edward Stillingfleet, An Answer to Mr. Locke's Second Letter (London, 1698), 175. See also 33- 44.

48 Locke, Essay, II.xxvii.3, 330.

49 Thiel, Early Modern Subject, 106. On Locke's distinction between the principium individuationis as an ontological notion and identity as an epistemic notion, see, also, K. J oanna S. Forstrom, J ohn Locke and Personal Identity: Immortality and Bodily Resurrection in 17th-Century Philosophy (London: Continuum, 2010), 18-24.

50 Locke, Essay, II.xxvii.29, 348. 
This said, although different people had different notions of "man," as Locke himself admitted (given his agnosticism on substance and given, also, his acknowledgment of human fallibility), he was persuaded that his own notion of "man" was the most appropriate and best-conforming to the idea of man "in most Peoples Sense." 51 His view of the identity of "man" is closely connected to his description of the identity of living creatures, which he distinguished from atoms and masses of atoms:

Let us suppose an Atom, i.e. a continued body under one immutable Superficies, existing in a determined time and place: 'tis evident, that, considered in any instant of its Existence, it is, in that instant, the same with it self. For being, at that instant, what it is, and nothing else, it is the same, and so must continue, as long as its Existence is continued: for so long it will be the same, and no other. In like manner, if two or more Atoms be joined together into the same Mass, every one of those Atoms will be the same, by the foregoing Rule: And whilst they exist united together, the Mass, consisting of the same Atoms, must be the same Mass, or the same Body, let the parts be never so differently jumbled: But if one of these Atoms be taken away, or one new one added, it is no longer the same Mass, or the same Body. In the state of living Creatures, their Identity depends not on a Mass of the same Particles; but on something else. ${ }^{52}$

According to Locke, the identity of living creatures depends on the continued organization of a common life-namely, on the continued organization of all their parts in a way fit to convey life to the whole creature. Accordingly, the principium individuationis of a living creature is the existence of an organized, common life. 53 This is also true for "man," in that human beings are living creatures. Locke indeed argued that "the Identity of the same Man consists . . . in nothing but a participation of the same continued Life, by constantly fleeting Particles of Matter, in succession vitally united to the same organized Body." 54 He further clarified that "tis not the Idea of a thinking or rational Being alone, that makes the Idea of a Man in most Peoples Sense; but of a Body so and so shaped joined to it." 55 Locke made a distinction between the identity of a "man" and that of a "person," in that in Essay II.xxvii.9 he located personal identity in "consciousness, which is inseparable from thinking." As Locke explained in this section of chapter 27:

51 Locke, Essay, II.xxvii.8, 335. See also Thiel, Early Modern Subject, 106.

52 Locke, Essay, II.xxvii.3, 330.

53 Locke, Essay, II.xxvii.3- 5, 330- 31.

54 Locke, Essay, II.xxvii.6, 331- 32. On Locke's concept of "man," see J ohn W. Yolton, The Two Intellectual Worlds of J ohn Locke: Man, Person, and Spirits in the "Essay" (Ithaca: Cornell University Press, 2004), 9- 37.

55 Locke, Essay, II.xxvii.8, 335. 
For since consciousness always accompanies thinking, and 'tis that, that makes every one to be, what he calls self; and thereby distinguishes himself from all other thinking things, in this alone consists personal Identity, i.e. the sameness of a rational Being: And as far as this consciousness can be extended backwards to any past Action or Thought, so far reaches the Identity of that Person; it is the same self now it was then; and 'tis by the same self with this present one that now reflects on it, that that Action was done. 56

To Locke, consciousness makes personal identity and also determines the principium individuationis of a person. In fact, the principium individuationis of a person defines what it is that makes an individual person the individual person this person is and that, therefore, distinguishes an individual person from all other individual persons. Here, however, a clarification of what "consciousness" means in Locke's philosophy is in order. To Locke, "consciousness" is "the perception of what passes in a Man's own mind." 57 In this regard, I find Shelley Weinberg's clarification of Locke's concept of consciousness very helpful: "[Consciousness] is a non-evaluative self-referential form of awareness internal to all perceptions of ideas. It is the perception that I am perceiving an idea, or the perception of myself as perceiving an idea. . . perceptions of ideas, for Locke, are complex mental states in which we are conscious of more than just the idea perceived. In any perception of an idea, there is, at the very least, an act of perception, an idea perceived, and consciousness (that I am perceiving)." 58

According to Locke, the fact of being conscious denotes an immediate awareness, which is a crucial part of all acts of thinking. Consciousness is, indeed, "inseparable from thinking." For this reason, to Locke consciousness is different from "reflection," which he describes as "the Perception of the Operations of our own Minds within us." 59 Reflection is not an essential element of thinking. In fact, reflection is relevant to contemplation (not to immediate awareness), because reflection takes place when the mind considers its own operations and objectifies them-or, in other words, produces ideas of them. Consciousness is also to be distinguished from intuition, which, in Locke's way of ideas, is immediate knowledge of self-evident truths. Intuition has a more limited scope than consciousness, because intuition, unlike consciousness, is not necessarily always present in thinking. Finally, there is a difference between consciousness and memory. While consciousness is an integral part of all acts of thinking at any time, memory consists of one's recollection of their experiences from the past. Thus, memory is only a part of consciousness-precisely that part of consciousness that, as Locke stated in an abovequoted passage from Essay II.xxvii.9, "as far as [it] can be extended backwards to any

56 Locke, Essay, II.xxvii.9, 335.

57 Locke, Essay, II.i.19, 115.

58 Shelley Weinberg, Consciousness in Locke (Oxford: Oxford University Press, 2016), xi.

59 Locke, Essay, II.i.4, 105. 
past Action or Thought, so far reaches the Identity of that Person; it is the same self now it was then; and 'tis by the same self with this present one that now reflects on it, that that Action was done." 60 Briefly, consciousness is more fundamental than reflection, has a broader scope than intuition, and is also broader than memory. Therefore, it is consciousness alone that makes personal identity. ${ }^{61}$ Nevertheless, in the Essay, the term "consciousness" seems to denote two different senses, as Weinberg has observed: "Locke seems to see consciousness as (1) a mental state inseparable from an act of perception by means of which we are aware of ourselves as perceiving, and (2) the ongoing self we are aware of in these conscious states." 62 While the first sense of consciousness signifies a momentary psychological state based on a momentary subjective experience, the second sense denotes the objective fact of the diachronic existence of a self "by the same consciousness." 63 Here, a problem arises, given that consciousness presents gaps, whereas life has no gaps. Locke considered this issue in Essay II.xxvii.20:

suppose I wholly lose the memory of some parts of my Life, beyond a possibility of retrieving them, so that perhaps I shall never be conscious of them again; yet am I not the same Person, that did those Actions, had those Thoughts, that I was once conscious of, though I have now forgot them? To which I answer, that we must here take notice what the Word I is applied to, which in this case is the Man only. And the same Man being presumed to be the same Person, I is easily here supposed to stand also for the same Person. 64

However, despite the undeniable gaps in consciousness, in this section of the Essay Locke still argued that consciousness alone makes personal identity:

But if it be possible for the same Man to have distinct incommunicable consciousness at different times, it is past doubt the same Man would at different times make different Persons; which, we see, is the Sense of Mankind in the solemnest Declaration of their Opinions, Humane Laws not punishing the Mad Man for the Sober Man's Actions, nor the Sober Man for what the Mad Man did, thereby making them two Persons; which is somewhat explained by our way of speaking in English, when we say such an one is not himself, or is besides himself;

60 Locke, Essay, II.xxvii.9, 335.

61 On the differences between consciousness, reflection, intuition, and memory in Locke's Essay, see Thiel, Early Modern Subject, 109- 20.

62 Weinberg, Consciousness, 153.

63 The phrase "by the same consciousness" appears in Locke, Essay, II.xxvii.10, 336, II.xxvii.21, 343, and II.xxvii.25, 345.

64 Locke, Essay, II.xxvii.20, 342. 
in which Phrases it is insinuated, as if those who now, or, at least, first used them, thought, that self was changed, the self same Person was no longer in that Man. ${ }^{65}$

Locke also emphasized that it is consciousness alone that makes an individual person the individual person that this person is, despite the temporal interruptions of consciousness, in section 10 of the same chapter, in which he argued that the question whether the same substance exists continuously is irrelevant to the question of personhood:

this consciousness, being interrupted always by forgetfulness, there being no moment of our Lives wherein we have the whole train of all our past Actions before our Eyes in one view: But even the best Memories losing the sight of one part whilst they are viewing another; and we sometimes, and that the greatest part of our Lives, not reflecting on our past selves, being intent on our present Thoughts, and in sound sleep, having no Thoughts at all, or at least none with that consciousness, which remarks our waking Thoughts. I say, in all these cases, our consciousness being interrupted, and we losing the sight of our past selves, doubts are raised whether we are the same thinking thing; i.e. the same substance or no. Which however reasonable, or unreasonable, concerns not personal Identity at all. The Question being what makes the same Person, and not whether it be the same Identical Substance, which always thinks in the same Person, which in this case matters not at all. Different Substances, by the same consciousness (where they do partake in it) being united into one Person; as well as different Bodies, by the same Life are united into one Animal, whose Identity is preserved, in that change of Substances, by the unity of one continued Life. For it being the same consciousness that makes a Man be himself to himself, personal Identity depends on that only, whether it be annexed only to one individual Substance, or can be continued in a succession of several Substances. For as far as any intelligent Being can repeat the Idea of any past Action with the same consciousness it had of it at first, and with the same consciousness it has of any present Action; so far it is the same personal self. For it is by the consciousness it has of its present Thoughts and Actions, that it is self to it self now, and so will be the same self as far as the same consciousness can extend to Actions past or to come. 66

Locke repeated the concepts expressed in the conclusion of this passage in other sections of Essay II.xxvii. For instance, in Essay II.xxvii.16 he maintained that "consciousness . . . unites Existences, and Actions, very remote in time, into the same Person, as well as it does the Existence and Actions of the immediately preceding moment." 67 In the next section, he further argued that consciousness is that "which makes the same Person, and

65 Locke, Essay, II.xxvii.20, 342- 43.

66 Locke, Essay, II.xxvii.10, 335- 36.

67 Locke, Essay, II.xxvii.16, 340. 
constitutes this inseparable self," and he declared that "That with which the consciousness of this present thinking thing can join it self, makes the same Person, and is one self with it, and with nothing else."68

The fact that consciousness makes personal identity has important practical, moral implications, because to Locke "in this personal Identity is founded all the Right and J ustice of Reward and Punishment."69 The moral aspects of Locke's theory of personal identity are manifest in his considerations on the continuity of personal identity, and hence of moral accountability, "by the same consciousness" during a person's life:

This every intelligent Being, sensible of Happiness or Misery, must grant, that there is something that is himself, that he is concerned for, and would have happy; that this self has existed in a continued Duration more than one instant, and therefore 'tis possible may exist, as it has done, Months and Years to come, without any certain bounds to be set to its duration; and may be the same self, by the same consciousness, continued on for the future. And thus, by this consciousness, he finds himself to be the same self which did such or such an Action some Years since, by which he comes to be happy or miserable now. In all which account of self, the same numerical Substance is not considered, as making the same self: But the same continued consciousness, in which several Substances may have been united, and again separated from it, which, whilst they continued in a vital union with that, wherein this consciousness then resided, madea part of that same self. 70

Locke needed to find a criterion for moral accountability that was not only based on a non-substantialist account of personhood, given his agnosticism on substance, but also different from spatio-temporally continuous, "ungapped" life, given his views on death and the resurrection of the dead. As I have said above, Locke explained in Essay II.xxvii.6 that the identity of a "man" consists in "a participation of the same continued Life, by constantly fleeting Particles of Matter, in succession vitally united to the same organized Body." 71 However, the hypothesis of "the same Man being presumed to be the same Person," which Locke considered and rejected in Essay II.xxvii.20, ${ }^{72}$ would be impractical on J udgment Day, given Locke's stance on the resurrection of the dead-not of their bodies. Locke admitted that life is "ungapped" and, thus, living creatures-and hence, also, human beings or, as he put it, "man"-are spatio-temporal continuous things in this life. But, given Locke's views on the soul's death and the resurrection of the dead (but not of their bodies), there is a gap and, consequently, no spatio-temporal continuity in human

68 Locke, Essay, II.xxvii.17, 341.

69 Locke, Essay, II.xxvii.18, 341.

70 Locke, Essay, II.xxvii.25, 345- 46.

71 Locke, Essay, II.xxvii.6, 331- 32.

72 Locke, Essay, II.xxvii.20, 342. 
beings between death and resurrection on J udgment Day. Nevertheless, there ought to be, and to Locke there is, indeed, some sort of continuity between one's self in their earthly life and in the afterlife upon resurrection, for resurrection is not a new beginning but a continuation of this self. Considering resurrection as a beginning would indeed be inconsistent with a corollary of Locke's notion of the principium individuationis, namely that all things only have a single beginning in time and place. For all these reasons, Locke's criterion for moral accountability ought to be, and indeed was, unrelated not only to the (unknown) substance(s) underlying a person's thinking and a person's life, but also to the unity of spatio-temporally continuous life. Locke's criterion for moral accountability was, simply, personal identity, which consciousness alone makes.

Locke described a "person" as a subject of accountability in two sections of Essay II.xxvii. 73 When distinguishing between "man" and "person" in Essay II.xxvii.9, he maintained that a person "is a thinking intelligent Being, that has reason and reflection, and can consider it self as it self, the same thinking thing in different times and places." 74 Every element of this definition is relevant to the moral implications of Locke's theory of personal identity, especially regarding reward and punishment. Reason, if utilized properly, is what allows a thinking, intelligent being to discern between what is moral and what is immoral. Reflection is necessary to realizing that one has freedom, which "consists in a Power to do, or not to do; to do, or forbear doing as we will."75 Reflection is actually necessary to recognizing that one has the power to suspend the carrying out of some action until investigation has revealed whether this action is compatible, or not, with one's true happiness. In this regard, it is worth noting that Locke saw true happiness as consistent with morality, since he equated the pursuit of true happiness to "the highest perfection of intellectual nature."76 Moreover, he insisted on the necessity of keeping in mind "the true intrinsick good or ill, that is in things" in order to act in accordance with "the eternal Law and Nature of things [which] must not be alter'd," thus complying with "the Will and Power of the Law-maker" - in this case, God - who has the power to reward and punish. ${ }^{77}$ As to considering "it self as it self, the same thinking thing in different times and places," without this ability a thinking, intelligent being could not act morally or recognize the justness of punishment or reward. In fact, one is punished or rewarded for what one has done at some other time and, in most cases, in some other place. Thus, one needs to consider oneself the same thinking thing at different times and places to make the connection between crime and punishment. Locke further elaborated on his notion of

73 On person as a subject of accountability in Locke, see Ruth Boeker, "The Moral Dimension in Locke's Account of Persons and Personal Identity," History of Philosophy Quarterly 31, no. 3 (2014): 239-41.

74 Locke, Essay, II.xxvii.9, 335.

75 Locke, Essay, II.xxi.56, 270.

76 Locke, Essay, II.xxi.51, 266.

77 Locke, Essay, II.xxi.53, 268; II.xxi.56, 271; II.xxviii.5, 351. On God's power to reward and punish, I say more below. 
person as a subject of accountability in Essay II.xxvii.26, in which he called attention to the moral and legal connotations of the term "person": "[Person] is a Forensick Term appropriating Actions and their Merit; and so belongs only to intelligent Agents capable of a Law, and Happiness and Misery. This personality extends it self beyond present Existence to what is past, only by consciousness, whereby it becomes concerned and accountable, owns and imputes to it self past Actions, just upon the same ground, and for the same reason, as it does the present."78

Locke's characterization and use of "person" as a forensic term denotes onemore point in common with the Socinian tradition, despite the Socinians' substantialist account of personhood. Concerning the equivalence of "person" and "substance," Socinus's and his followers' understanding of "person" was inspired by the Boethian view of personhood. However, in regard to the moral and legal aspects of personhood, the Socinians' views were indebted to Roman law, in which the word "persona" is a forensic term. As Sarah Mortimer has observed, "all Roman law 'has to do with persons, things and actions,' and the implication was that personality (not essence or substance) was the key characteristic of an active entity." 79 Briefly, both the Socinians and Locke paid great attention to "person" as a thinking, intelligent moral agent. This has led some historians, such as J . L. Mackie and Gideon Yaffe, to overemphasize the moral and legal aspects of Locke's theory of personal identity. Mackie has even stated that Locke's theory is "hardly a theory of personal identity at all, but might be better described as a theory of action appropriation." 80 Yaffe has argued that, in Locke's theory, it is the suitability of rewards and punishments to function as a criterion of personal identity and that, therefore, Locke "is reversing the assumed order of priority of the metaphysical and the moral." $81 \mathrm{I} \mathrm{am}$ convinced, however, by David Anderson's and Udo Thiel's responses to Yaffe, which

78 Locke, Essay, II.xxvii.26, 346. When Locke, in this passage, mentions "Actions and their Merit," I believe that he is referring to the intrinsic worth of actions-not to the value assigned to actions by the (fallible) person committing such actions. As I have explained above, Locke indeed believed in the existence of "the true intrinsick good or ill, that is in things" and argued that "the eternal Law and Nature of things must not be alter'd" (Locke, Essay, II.xxi.53, 268; II.xxi.56, 271).

79 Sarah Mortimer, Reason and Religion in the English Revolution: The Challenge of Socinianism (Cambridge: Cambridge University Press, 2010), 35.

80 J. L. Mackie, Problems with Locke (Oxford: Clarendon Press, 1976), 183. Other interpreters, including Antonia LoLordo in Locke's Moral Man (Oxford: Oxford University Press, 2012), describeLocke's account of personal identity in terms of appropriation. Although a detailed discussion of this issue is irrelevant to my point in this article, I would like to refer the reader to Ruth Boeker's thought-provoking questioning of so-called appropriation interpretations in: Ruth Boeker, "The Role of Appropriation in Locke’s Account of Persons and Personal Identity," Locke Studies 16 (2016): 3- 39.

81 Gideon Yaffe, "Locke on Ideas of Identity and Diversity," in The Cambridge Companion to Locke's "Essay concerning Human Understanding”, edited by Lex Newman (Cambridge: Cambridge University Press, 2007), 227. 
reaffirm that Locke's theory is actually a theory of personal identity. ${ }^{82}$ In Thiel's words: "[Yaffe's] reading is hardly compatible with Locke's text, however. For Locke, personal identity is the foundation for 'all the Right and Justice of Reward and Punishment' (Essay, II.xxvii.18). Identity, for Locke, is presupposed by appropriate rewards and punishments. Thus, the latter cannot function as criteria of the former. Pace Yaffe, for Locke personal identity cannot 'consist in any thing but consciousness' (Essay, II.xxvii.21)."83 In other words, to Locke personal identity, which consciousness alone makes, is ontologically prior to moral accountability, although, as Shelley Weinberg has correctly observed, "Locke's theory of personal identity is meant to complement his moral and theological commitments to a system of divine punishment and reward in an afterlife." 84 It is to these moral and theological commitments to a system of otherworldly rewards and sanctions that I turn my attention now.

\section{Salvation}

The moral implications of Locke's theory of personal identity informed his reflections on the Last J udgment. Udo Thiel has noted that, according to Locke, "moral responsibility is founded in personal identity and personal identity in consciousness." 85 This conviction contradicts original sin - a doctrine that Locke expressly rejected in various manuscripts and public writings on religion, including The Reasonableness of Christianity. ${ }^{86}$ In the opening pages of this book, he indeed blamed "some Men [who] would have all Adam's Posterity doomed to Eternal Infinite Punishment for the Transgression of Adam, whom Millions had never heard of, and no one had authorized to transact for him, or be his Representative." 87 In two manuscripts he composed a couple of years before the Reasonableness, namely "Peccatum originale" (1692) and "Homo ante et post lapsum"

82 David J . Anderson, "Susceptibility to Punishment: A Response to Yaffe," Locke Studies 8 (2008): 101- 6; Thiel, Early Modern Subject, 214- 15.

83 Thiel, Early Modern Subject, 215.

84 Shelley Weinberg, “Locke on Personal Identity,” Philosophy Compass 6, no. 6 (2011): 398. See also Boeker, "Moral Dimension," 242. Several contemporaries, or almost contemporaries, of Locke, such as Bishop Edward Stillingfleet and, after Locke's death, the Nonconformist Congregationalist ministers Isaac Watts and Philip Doddridge and the Church of England clergyman J oseph Butler, concentrated mainly on the metaphysical implications of his theory of personal identity -and not on the moral aspects of this theory - when attacking his views on the resurrection of the dead. On this debate, see Alan P. F. Sell, J ohn Locke and the Eighteenth-Century Divines (Cardiff: University of Wales Press, 1997), 239- 67.

85 Thiel, Early Modern Subject, 131.

86 On Locke's views on original sin, see William M. Spellman, John Locke and the Problem of Depravity (Oxford: Clarendon Press, 1988); Aderemi Artis, "Locke on Original Sin," Locke Studies 12 (2012): 201- 19.

87 Locke, Reasonableness, 5. 
(1693), he objected to the theory that Adam's sin was imputed to his posterity, he denied the fallen condition of humankind following Adam's sin, and he described the doctrine of original sin as illogical and incompatible with God's goodness and justice. 88 Consequently, he did not approve of the satisfaction theory of atonement, according to which Christ suffered death on the cross as a substitute for human sin, thus satisfying God due to his infinite merit. Conversely, he saw Christ's death as necessary to reaffirm the truth of his doctrine, thus expressing a position in line with the Arminians' governmental theory of atonement, first formulated by Grotius and then upheld and refined by Limborch. ${ }^{89}$ According to the Arminians' account of atonement, God offered Christ's death as a public display of how seriously he takes sin, in order to uphold his moral government of the world. Whereas Locke did not expressly deny satisfaction, a position similar to the Arminians' governmental theory emerges in several of his writings on religion, most prominently in the manuscript "Adversaria Theologica," which describes Christ's death on the cross as necessary to confirm the truth of his doctrine. 90 To Locke, salvation is indeed a matter of individual responsibility. In other words, Locke believed that the individual ought to earn their own salvation through their works and faith during their earthly life, as I explain below.

Essay II.xxvii, too, presents several passages incompatible with the doctrine of original sin and affirming, instead, the principle of individual responsibility in matters relevant to salvation. In Essay II.xxvii.26, Locke wrote that only one's own actions will be considered on J udgment Day, when "the Sentence shall be justified by the consciousness all Persons shall have, that they themselves in what Bodies soever they appear, or what Substances soever that consciousness adheres to, are the same, that committed those Actions, and deserve that Punishment for them." 91 Moreover, he considered the possibility that a person's memory is transferred to another person-a possibility entailing that one might be rewarded and punished for another's actions. However, he trusted "the Goodness of God, who as far as the Happiness or Misery of any of his sensible Creatures is concerned in it, will not by a fatal Error of theirs transfer from one to another, that consciousness, which draws Reward or Punishment with it."92 In Essay II.xxvii.22, he maintained that "in the great Day, wherein the Secrets of all Hearts shall be laid open, it may be reasonable to think, no one shall be made to answer for what he knows nothing

88 J ohn Locke, "Peccatum originale," in Writings on Religion, 229- 30; J ohn Locke, "Homo ante et post lapsum," in Writings on Religion, 231.

89 Hugo Grotius, Defensio fidei Catholicae de satisfactione Christi adversus Faustum Socinum (Leiden, 1617), 56- 157; Philipp van Limborch, Theologia Christiana (Amsterdam, 1686), 224- 41, 264- 73.

90 Locke, "Adversaria Theologica," 33.

91 Locke, Essay, II.xxvii.26, 347.

92 Locke, Essay, II.xxvii.13, 338. 
of; but shall receive his Doom, his Conscience accusing or excusing him."93 In this passage, Locke used a formula borrowed from 1 Cor. 14:25 ("And thus are the secrets of his heart made manifest"), which he also referred to a few paragraphs below in the same chapter: "the Apostle tells us, that at the Great Day, when every one shall receive according to his doings, the secrets of all Hearts shall be laid open."94 Briefly, Locke's persuasion that, on J udgment Day, "no one shall be made to answer for what he knows nothing of" and "every one shall receive according to his doings" is logically inconsistent with the idea that human beings are to be held accountable for another person's deeds and, hence, for Adam's sin. Locke's position on this matter is also inconsistent with a view of Christ as a substitute for human sin - a view that is at the basis of the satisfaction theory of atonement.

Concerning the Last Judgment, Udo Thiel has argued that there is a dichotomy between Locke's consciousness-based theory of personal identity and his notion of repentance, which The Reasonableness of Christianity describes as necessary to salvation. Calling attention to Essay II.xxvii.22, Thiel has maintained the following:

if I am still conscious of my "past misdeeds," Locke would have to say that despite my genuine repentance I would nevertheless be subject to punishment for them, because "punishment [is] annexed to personality, and personality to consciousness." Thus it seems that repentance, even of the kind that Locke envisages, is not consistent with his account of personal identity in terms of consciousness. His distinction between thinking substance, man, and person does not help here. The inconsistency concerns his notion of repentance and his claim that just rewards and punishments depend only on consciousness. 95

Briefly, in Thiel's opinion, one's consciousness of their past misdeeds still makes one subject to punishment and, consequently, this will result in punishment on the Last Judgment, regardless of their repentance. However, nowhere does Locke claim (as Thiel argues) that "just rewards and punishments depend only on consciousness." Moreover, Thiel neglects two other, interconnected points in Locke's soteriology, which Locke explained in the Reasonableness and which I clarify below in this article. These two important points in Locke's soteriology are (1) that repentance is necessary but not sufficient to salvation and (2) that the fact that a sin deserves punishment does not mean that God will necessarily punish the sinner. Finally, and incidentally, Thiel does not consider the case of misdeeds one commits against their will, although another condition for punishment is freedom. If one is forced to perform a criminal act, this person can be

93 Locke, Essay, II.xxvii.22, 344.

94 Locke, Essay, II.xxvii.26, 347. Here, Locke also drew on, and explicitly referred to, 2 Cor. 5:10: “For we must all appear before the judgment seat of Christ; that every one may receive the things done in his body, according to that he hath done, whether it be good or bad."

95 Thiel, Early Modern Subject, 143. 
conscious of it. However, it would be unjust to punish this person for this act, because this person lacked freedom to do otherwise.

Galen Strawson, too, has discussed the apparently problematic relationship between Locke's theory of personal identity and his views on repentance. Commenting on Essay II.xxvii, Strawson has written that "guilt (apart from being a painful emotion) is surely a form of Concernment, and entails Consciousness; and Consciousness entails same Personhood; and same Personhood entails present accountability and punishability."96 Strawson has stressed the inseparableness of consciousness and concernment regarding a person's past misdeeds, given also that repentance might not cancel one's consciousness of, and concernment with, their past misdeeds. Therefore, he has observed that, given Locke's account of personal identity and punishment, the latter seems unavoidable on Judgment Day: "Tying punishment and reward to actual Consciousness and Concernment isn't going to allow anyone to get away with anything they shouldn't get away with, for what one is Conscious of-what one still feels Concerned or involved inis, again, not something one can do anything about, on Locke's view." ${ }^{\prime 7}$ However, in an attempt to accommodate repentance, Strawson has hypothesized that repentance might also lead one to lose consciousness of their past misdeeds:

If Consciousness is genuinely lost, . . . then Locke's theory gives the right result. The person one is now can't be rightly punished for the action of which Consciousness has been lost. This core idea lifts easily out of its eschatological context, and seems better expressed in an entirely nonreligious and nonepistemological way. It's simply the idea that there is at any time a fact of the matter about a person's overall moral nature, shape, constitution, or being, whether or not it is ever revealed or made the basis of action. This is an idea that has considerable resonance and plausibility for many people. One's moral identity is not simply a matter of an accumulated bag of actions. It's something that can change (e.g. improve) over time, and not just by a change in the proportion of good and bad actions in the bag. And this improvement can be not only correlative with, but also partly constitutive of, one's losing touch with some of one's past actions in such a way that one is no longer appropriately punished for them. 98

Nevertheless, as Strawson himself has recognized, this solution rests on "one terminological choice among others, made to suit a case that Locke didn't consider in print." 99 It is instead likely that, as Strawson himself has noted, to Locke "our capacities

96 Strawson, Locke on Personal Identity, 140.

97 Strawson, Locke on Personal Identity, 143.

98 Strawson, Locke on Personal Identity, 148- 49.

99 Strawson, Locke on Personal Identity, 147. 
for recall will be exceptionally vivid on the Day of J udgment." 100 In an above-cited passage from the Essay, II.xxvii.22, Locke actually stated that "in the great Day ... the Secrets of all Hearts shall be laid open." 101 It is thus to be expected that, on J udgment Day, we will be able to remember our past actions accurately - that is, in Locke's words, we will be able to "repeat the Idea of any past Action with the same consciousness [we] had of it at first, and with the same consciousness [we have] of any present Action." 102 In fact, when talking of J udgment Day in an above-quoted passage from Essay II.xxvii.26, Locke mentioned "the consciousness all Persons shall have, that they themselves . . . are the same, that committed those Actions." 103 However, while implicitly dismissing the aforesaid, illgrounded option, Strawson takes into account another solution: "Alternatively, the gap can be closed by appeal to God's mercy. On this view one is indeed still punishable for absolutely everything one is Conscious of, and one is still Conscious of absolutely everything one experiences as one's own, even if one now experiences it as one's own only in a wholly affectively neutral, wholly morally disengaged way. Nevertheless, God won't actually punish one for any of the things from which one has disengaged."104

Whereas this option is more plausible than Strawson's other hypothesis, he does not endorse it expressly, perhaps because he does not support it with a thorough analysis of Locke's views on salvation. Moreover, the scarce attention that Strawson pays to Locke's soteriology leads him to suppose, incorrectly, that one's "appeal to God's mercy" enables one to experience their past misdeeds "in a wholly affectively neutral, wholly morally disengaged way." However, Locke's account of repentance in The Reasonableness of Christianity does not involve affective neutrality or moral disengagement from one's past sins. To Locke, sincere repentance actually brings about a moral renovation in the repentant faithful, thanks to the latter's acknowledgment of, and sorrow for, their misdeeds. The repentant faithful must feel a genuine sorrow for both the evil actions committed before conversion and the sins committed after conversion, while attempting to live the Christian life, because even those who endeavor to abide by the divine law are not exempt from sin. And this sorrow must be accompanied by a genuine endeavor to obey the divine moral law, because, according to Locke, without repentance for all sins and without the consequent, sincere effort to abide by the divine law it is impossible to achieve a moral renovation and strive to live an exemplary life:

100 Strawson, Locke on Personal Identity, 148.

101 Locke, Essay, II.xxvii.22, 344.

102 Locke, Essay, II.xxvii.10, 336. It is worth clarifying that one's ability to have accurate memories of their past sins on J udgment Day does not mean that an unrepentant sinner will necessarily repent at the Last Judgment. In fact, Locke never considered the possibility (and effectiveness) of post-mortem repentance.

103 Locke, Essay, II.xxvii.26, 347.

104 Strawson, Locke on Personal Identity, 147. 
[Repentance is] not only a sorrow for sins past, but (what is a Natural consequence of such sorrow, if it be real) a turning from them, into a new and contrary Life. ... Repentance is an hearty sorrow for our past misdeeds, and a sincere Resolution and Endeavour, to the utmost of our power, to conform all our Actions to the Law of God. So that Repentance does not consist in one single Act of sorrow ... But in doing works meet for Repentance, in a sincere Obedience to the Law of Christ, the remainder of our Lives. ${ }^{105}$

This attitude, I think, is far from entailing affective neutrality or moral disengagement. It is true that one's repentance for their past misdeeds, along with a sincere and constant effort to lead a righteous life, does not cancel these misdeeds and, thus, does not make them less deserving of punishment. This is indeed the case in human affairs, in which repentance for one's crime, accompanied by one's commitment to live a just life, does not exempt the culprit from punishment. As regards human justice, according to Locke, even one's (momentary) unconsciousness, and subsequent lack of memory, of their own misdeeds is not an excuse strong enough to exempt the offender from punishment. Locke's position on this matter emerges from the famous passage about the drunk and sober man in Essay II.xxvii.22, which is the same passage Thiel refers to, and partly quotes, when claiming that Locke's theory of personal identity contradicts his notion of repentance: "For though punishment be annexed to personality, and personality to consciousness, and the Drunkard perhaps be not conscious of what he did; yet Humane Judicatures justly punish him; because the Fact is proved against him, but want of consciousness cannot be proved for him."106

Nevertheless, when it comes to eternal salvation, things are more complex. In a previously quoted passage from Essay II.xxvii.22, Locke wrote that, on Judgment Day, everyone "shall receive his Doom, his Conscience accusing or excusing him."107 Harold Noonan has suggested that, in this passage, Locke uses the term "conscience" as a synonym for "consciousness." 108 This interpretation supports the view that, to Locke, all that counts when it comes to divine punishment is one's awareness of their actions, including their sinful actions. I disagree with Noonan. Given also that this is the only place

105 Locke, Reasonableness, 111- 12. Incidentally, the fact that repentance must be accompanied by obedience does not make death-bed repentance pointless. In the passage I have quoted here, Locke was clear that what counts, in repentance, is "a sincere Resolution and Endeavour, to the utmost of our power, to conform all our Actions to the Law of God." And if one, upon repenting genuinely, fails to translate this "sincere Resolution" into actions because of their death, one is not accountable for this failure and it would consequently be unjust to penalize them for this.

106 Locke, Essay, II.xxvii.22, 344.

107 Locke, Essay, II.xxvii.22, 344.

108 Harold W. Noonan, "Locke on Personal Identity," in John Locke, An Essay concerning Human Understanding in Focus, edited by Gary Fuller, Robert Stecker, and J ohn P. Wright (London: Routledge, 2000), 232. 
in Essay II.xxvii where Locke uses the term "conscience," I believe that, by "conscience," here Locke means the same thing he does in Essay I.iii.7-9, in which he defines conscience as "our own Opinion or J udgment of the Moral Rectitude or Pravity of our own Actions." 109 In other words, conscience is one's own moral evaluation of one's deeds, whereas consciousness is non-evaluative awareness. Locke's discussion of this subject in Essay I.iii.7-9 indeed shows that what he means by "opinion or judgment" is not mere consciousness-i.e., non-evaluative awareness-of our actions. What Locke means by "opinion or judgment" is actually an assessment of our actions that, if matched by a proper consideration of the eternal moral law, is accompanied by a sound judgment of their righteousness or wrongness and, hence, by feelings of confidence and serenity in the case of just actions, or by remorse in the case of misdeeds. ${ }^{110}$ Therefore, I believe that when Locke states in Essay II.xxvii.22 that, on J udgment Day, everyone "shall receive his Doom, his Conscience accusing or excusing him,"111 he is talking of not only one's awareness of their sins, but also of whether one, during their earthly life, has understood, or not, the evilness of these sins and has felt remorse, or not, for these sins. In other words, pace Noonan (and Thiel, too), the appropriateness of one's moral evaluation of their sins and, hence, one's repentance (or lack thereof) for these sins during their life - and not simply one's (non-evaluative) awareness thereof-will be taken into consideration on the Last Judgment. And, as we have seen above, repentance must be accompanied by a genuine effort to abide by the divine moral law.

In The Reasonableness of Christianity, however, Locke argued that one's salvation depends not only on their repentance for their sins and on the consequent commitment to obey the divine moral law, but also on one's faith and conscientious study of Scripture. To Locke, repentance for one's sins, obedience to the divine law, and faith in J esus the Messiah are the fundamentals of Christianity, which he considered plainly revealed in Scripture. ${ }^{112}$ Therefore, acceptance of the three fundamentals binds one to Scripture as a whole, which the faithful has a duty to study diligently. Locke allowed for mistakes in the interpretation of biblical passages concerning non-fundamental issues, as long as such mistakes are made in bona fide and do not lead to enmity with, or persecution of, other believers. He even argued that error on non-fundamentals, when held after sincere search by a Christian, is saving; but he considered acceptance of the three fundamentals crucial to conduct a Christian life and pursue salvation. ${ }^{113}$ According to Locke, disregard for the fundamentals of Christianity when reading Scripture was indeed likely to lead to either one of two diametrically opposed but equally undesirable extremes-antinomianism,

109 Locke, Essay, I.iii.8, 70.

110 Locke, Essay, I.iii.7-9, 69- 72.

111 Locke, Essay, II.xxvii.22, 344.

112 Locke, Reasonableness, 109- 12.

113 Locke, Reasonableness, 168- 71. 
which entailed a radical sort of predestinarianism, or deism, which affirmed reliance on the Law of Nature alone and portrayed Christ as simply the restorer of the Law of Nature and, hence, as merely a preacher of natural religion. While rejecting predestination, Locke also disapproved of the deists' notion of natural religion as actually conducive to morality and sufficient to salvation, because he recognized the imperfection and weakness of human nature. He considered the Law of Nature as a divinely established system of morality, which exists eternally and immutably and is compatible with natural reason. But he maintained that unassisted reason had always failed to grasp the Law of Nature in its entirety: "'tis too hard a task for unassisted Reason to establish Morality in all its parts upon its true foundation; with a clear and convincinglight. ... Humane reason unassisted, failed Men in its great and Proper business of Morality. It never from unquestionable Principles, by clear deductions, made out an entire body of the Law of Nature."114

This failure was due not only to the detrimental effects of ecclesiastical tradition, priestcraft, and power politics on the human ability to reason, which Locke denounced in the Reasonableness, ${ }^{115}$ but also to difficulties intrinsic to a possible scientia of morality. For most of his life, Locke struggled to find scientific grounds for morality. He was not skeptical about the existence, rationality, and demonstrability of morality in itself. In the Essay, he placed "Morality amongst the Sciences capable of Demonstration."116 However, he doubted that natural reason alone could actually demonstrate moral ideas and, thus, find solid epistemological foundations for morality. In the Essay, he called attention to the difficulties that reason meets when trying to demonstrate moral ideasdifficulties like their unfitness for sensible representation and their complexity. ${ }^{117} \mathrm{He}$ argued that these difficulties "may in a good measure be remedied by Definitions, setting down that Collection of simple Ideas, which every Term shall stand for; and then using the Terms steadily and constantly for that precise Collection." Nevertheless, he observed that, in fact, the imperfection and weakness of human nature had always prevented human beings from demonstrating moral ideas; and he was pessimistic about the prospect of improvement in this regard: "much of this [i.e., a demonstration of morality] is not to be expected, whilst the desire of Esteem, Riches, or Power makes Men espouse the well-endowed Opinions in Fashion, and then seek Arguments, either to make good their Beauty, or varnish over, and cover their Deformity."118

Locke himself, in the Essay, did not provide a demonstration of morality consistent with his way of ideas, in that he did not clarify the very idea of moral obligation. ${ }^{119}$ Locke's

114 Locke, Reasonableness, 148- 50.

115 Locke, Reasonableness, 161- 63.

116 Locke, Essay, IV.iii.18, 549.

117 Locke, Essay, IV.iii.19, 550- 52.

118 Locke, Essay, IV.iii.20, 552.

119 Locke, Essay, II.xxii.1- 12, 88- 95; J . B. Schneewind, "Locke's Moral Philosophy," in The Cambridge Companion to Locke, edited by Vere Chappell (Cambridge: Cambridge University Press, 1994), 213. When 
skepticism about the powers of natural reason in moral matters eventually led him to decidedly turn to biblical theology in the Reasonableness. According to Locke, given the failure of unassisted reason to comprehend the Law of Nature in its entirety, God had expressly reaffirmed the universal and eternal Law of Nature through the covenant of works, establishing the Law of Moses. This new law consisted of two parts-ritual prescriptions and moral precepts. These moral precepts, which Locke called "the Law of Works," were identical to the Law of Nature and, hence, had eternal validity, whereas the ceremonial part of the Law of Moses had "a limited and only temporary Obligation." The main advantage of the Law of Works over the Law of Nature was that the former was stated clearly in the Old Testament and was, therefore, easily accessible. Nevertheless, the Law of Moses, like the Law of Nature, was excessively rigorous, in that it demanded perfect obedience, and offered no incentive to act morally. This is why a new covenantthe covenant of grace or covenant of faith-was needed. With this new covenant, Christ established the Law of Faith, disclosing the God-given, inherently rational, and eternally valid Law of Nature in its entirety, but complementing it with new truths, namely the assurance of otherworldly rewards and sanctions and the promise of God's mercy - truths unattainable by natural reason alone, although reasonable and hence acceptable to natural reason once revealed. ${ }^{20}$ The prospect, offered by Christ, of reward and punishment in the afterlife gave human beings a powerful incentive to behave morally. 121 Locke had already hinted at an afterlife with reward and punishment as a strong incentive to act morally in the Essay. In II.xxi.60, he had indeed talked of "a prospect of the different State of perfect Happiness or Misery, that attends all Men after this Life, depending on their Behaviour here." 122 Moreover, in II.xxviii.8, he had stated: "God has given a Rule whereby Men should govern themselves ... . He has a Right to do it, we are his Creatures: He has Goodness and Wisdom to direct our Actions to that which is best: and he has Power to enforce it by Rewards and Punishments, of infinite weight and duration, in another Life."123

It was, however, in the Reasonableness and the Paraphrase that Locke emphasized this "advantage of Christ's coming," which was also one of the central tenets of

working on the Essay in the 1680s, Locke made an attempt at a system of ethics in the manuscript "Of Ethick in General" (ca. 1686), originally intended as the final chapter of the Essay. However, he eventually discarded this project and left this manuscript incomplete. See J ohn Locke, "Of Ethick in General," in Writings on Religion, 9- 14; Nuovo, J ohn Locke, 193- 97.

120 Locke, Reasonableness, 16- 22.

121 Locke, Reasonableness, 21-25, 110-12, and 132. See also: John Locke, "Voluntas," in Locke: Political Essays, edited by Mark Goldie (Cambridge: Cambridge University Press, 1997), 321 (a manuscript note written in 1693-94).

122 Locke, Essay, II.xxi.60, 274.

123 Locke, Essay, II.xxviii.8, 352. On Locke's hints at God's power and the prospect of an afterlife with reward and punishment in the Essay, see Nuovo, J ohn Locke, 182- 213. 
Socinianism. Both Locke and the Socinians believed "that before Christ's coming mankind as a whole had no reason to believe that there was a law of right and wrong, enforced by other-worldly punishments, for they had no reason to expect a life after death." 124 This, however, does not mean that humankind did not have a reason to behave morally before Christ's assurance of otherworldly sanctions. In fact, although Locke considered the prospect of reward or punishment in the afterlife as an effective incentive to promote moral practice, his ethics was not a "mercenary" ethics, as some interpreters have argued. ${ }^{125}$ Locke never abandoned his conviction in the existence of a universal, eternal, intrinsically rational, God-given moral law-namely, the Law of Nature. He regarded belief in a divine creator and legislator as necessary to moral conduct. To Locke, belief in God, which can be reached through the operation of natural reason, indeed entails that we, as God's creatures, owe obedience to God's law. In the Second Treatise and the Essay, Locke actually stated that human beings are the workmanship, servants, and property of the divine creator and legislator and are "sent into the World by his order, and about his business." 126 Thus, he regarded obedience to the divine moral law as primarily a duty, even regardless of reward or punishment in the afterlife, which he considered as simply an incentive to moral conduct-not as the main motivation to act morally. Briefly, to Locke the principles of the Law of Nature have more of an intrinsic value than an imputed value in terms of justification, although obedience to the divine moral law plays an important role in the pursuit of salvation. In this regard, it is worth noting that Locke's stress on the intrinsic value and eternal validity of the Law of Nature distinguishes him from the Socinians, who saw the Law of Nature as partly invalidated and hence replaced by the revealed law, but is a point in common with the Arminian tradition, which highlights the cooperation between nature and grace in salvation.

Nevertheless, although Locke argued that the Law of Faith had reaffirmed the Law of Nature and had complemented it with a strong incentive to moral conduct, he did not claim that accepting the Law of Faith and, thus, believing in an afterlife with reward and punishment leads, necessarily and unfailingly, to act morally. In both the Essay and the Reasonableness, he admitted that even those who believe in otherworldly rewards and sanctions are still liable to commit evil deeds, given the imperfection and weakness of human nature. ${ }^{127}$ As Alan Sell has noted, "Locke, though insisting on human rationality,

124 David Wootton, “J ohn Locke: Socinian or Natural Law Theorist?,” in Religion, Secularization and Political Thought: Thomas Hobbes to J.S. Mill, edited by James E. Crimmins (London: Routledge, 1989), 49.

125 See, for instance, Michael S. Rabieh, "The Reasonableness of Locke, or the Questionableness of Christianity,” The J ournal of Politics 53, no. 4 (1991): 933- 57.

126 J ohn Locke, Two Treatises of Government, edited by Peter Laslett (Cambridge: Cambridge University Press, 1988), 271; Locke, Essay, IV.iii.18, 549.

127 Locke, Essay, II.xxi.60- 73, 273- 87; II.xxviii.12, 356- 57; Locke, Reasonableness, 19, 120, and 130. 
never lost sight of the reality of actual and universal human moral weakness and sin." 128 Therefore, Locke shared another important tenet of Socinian soteriology-belief in God's mercy, which Locke emphasized as an important advantage of Christ's coming. Like Socinus and his followers, Locke believed that Christ had given humanity a concrete hope of salvation, despite the limits, imperfection, and weakness of human nature. To the Socinians and Locke, the New Testament highlights God's forgiveness of the sins committed by the repentant faithful who, in their life, have sincerely attempted to obey the divine law but have sometimes failed to obey it because of their weakness and imperfection. In De J esu Christo Servatore (1594), Socinus, distinguishing between human and divine justice, denied that God necessarily ought to punish the sinner. He claimed, instead, that God is merciful and omnipotent and, thus, not bound by any law, unlike civil magistrates. Moreover, God knows whether one is truly a believer, who is actually repentant and sincerely committed to obey the divinelaw. Therefore, Socinus and his disciples, particularly J ohann Crell, argued that God could waive his right to punishment and, consequently, forgive the repentant faithful despite their sins-even though these sins are still deserving of punishment. ${ }^{129}$ When explaining why faith is one of the fundamentals of Christianity, Locke expounded a view in line with the Socinians' position. To Locke, Christ "did not expect . . . a Perfect Obedience void of slips and falls: He knew our Make, and the weakness of our Constitution too well, and was sent with a Supply for that Defect." 130 Here, Locke is obviously talking of faith, since "Faith is allowed to supply the defect of full Obedience; and so the Believers are admitted to Life and Immortality as if they were Righteous." 131 However, Locke did not believe in salvation by faith alone. In Locke's soteriology, the justifying faith includes good works, as Dewey Wallace has pointed out: "By the law of faith Locke does not intend a new way of serving God but the same moral law, which may, however, under the new covenant be only partially fulfilled, the defect in its fulfillment being compensated for by the faith of the believer." 132

This means that a sincere effort to obey God's moral law is still required of Christians to achieve salvation. At the same time, one's faith, too, along with their repentance for their sins committed both before and after conversion to the Christian life, will be taken into account on J udgment Day, as Locke explained in the Reasonableness:

128 Sell, J ohn Locke, 230. See also Spellman, J ohn Locke, 57.

129 Faustus Socinus, “De J esu Christo Servatore," in Fausti Socini Senensis Opera Omnia, volume 2 of Bibliotheca Fratrum Polonorum quos Unitarios vocant, 9 vols. (Irenopoli [Amsterdam], post annum Domini 1656 [1665- 1692]), 121- 32; J ohannes Crellius, Ad librum Hugonis Grotii (Racoviae [Raków], 1623), $164-67$.

130 Locke, Reasonableness, 120.

131 Locke, Reasonableness, 19.

132 Dewey D. Wallace, “Socinianism, Justification by Faith, and the Sources of J ohn Locke's The Reasonableness of Christianity," J ournal of the History of Ideas 45, no. 1(1984): 53- 54. 
[Christ's followers] were required to believe him to be the Messiah; Which Faith is of Grace promised to be reckoned to them for the compleating of their Righteousness, wherein it was defective: But Righteousness, or Obedience to the Law of God, was their great business; Which if they could have attained by their own Performances, there would have been no need of this Gracious Allowance, in Reward of their Faith. . . . But their past Transgressions were pardoned, to those who received J esus, the promised Messiah, for their King; And their future slips covered, if renouncing their former Iniquities, they entered into his Kingdom, and continued his Subjects, with a steady Resolution and Endeavour to obey his Laws. This Righteousness therefore, a compleat Obedience and freedom from Sin, are still sincerely to be endeavoured after. And 'tis no where promised, That those who persist in a wilful Disobedience to his Laws, shall be received into the eternal bliss of his Kingdom, how much soever they believe in him. ${ }^{133}$

Therefore, the repentant faithful, who in their life have sincerely endeavored to obey the divine law and to understand and live by God's Revealed Word, will receive "the Pardon and Forgiveness of Sins and Salvation." 134 To Locke, God will show his mercy to the repentant faithful and will not punish them, despite their consciousness of their sins and despite these sins being deserving of punishment.

\section{Conclusion}

In this article, I have argued that Locke's consciousness-based theory of personal identity, explained in book 2, chapter 27 of An Essay concerning Human Understanding, is compatible with his soteriology, and hence with his stance on the resurrection of the dead, the Last J udgment, and divine reward and punishment in theafterlife, which he explained in The Reasonableness of Christianity and other theological writings. I have paid special attention to the role of repentance in the pursuit of salvation according to Locke, because of Udo Thiel's and Galen Strawson's points on the apparent incompatibility of Locke's notion of repentance with his consciousness-based theory of personal identity. I have argued that Thiel's and Strawson's conclusions on this issue are mistaken for different reasons - mainly because these two authors have abstracted Locke's notion of repentance from his soteriology taken as a whole. An accurate examination of Locke's soteriology demonstrates that, according to Locke, reward and punishment in the afterlife depend neither on consciousness alone nor simply on repentance. According to Locke, repentance for one's sins is actually necessary but not sufficient to salvation, because repentance is only one element in the pursuit of salvation. Repentance alone, without obedience to the divine moral law and faith in Jesus the Messiah, is ineffective to salvation. Even repentance and obedience together, without faith, cannot lead to salvation, because the limits, imperfection, and weakness of human nature make perfect obedience to the divine

133 Locke, Reasonableness, 130.

134 Locke, Reasonableness, 133. 
moral law impossible. Thus, faith in J esus the Messiah and his salvific message, which is known through Scripture, is needed "to supply the defect of full Obedience." And this is the main reason why Locke disagreed with the deists' reliance on natural reason, and hence on the Law of Nature, alone. Likewise, faith alone does not justify, since Locke, who rejected antinomianism and any sort of predestinarianism, believed that the justifying faith involves good moral works. Locke indeed considered J esus' message as truly salvific for two main reasons. The first reason is that J esus, besides reaffirming the divinely given, inherently rational, and eternal Law of Nature, assured humanity of otherworldly rewards and sanctions, thus providing an incentive to act morally. The second, and more important, reason is that J esus knew of the weakness and imperfection of human nature and, thus, he was aware of the unavoidability of sin on the part of human beings - even on the part of the most sincere and committed believers. Therefore, J esus emphasized God's mercy and, hence, God's power to abstain from punishing the repentant faithful for their sins, even when these sins are still deserving of punishment. Far from expecting perfect obedience, under the new covenant God admits the faithful "to Life and Immortality as if they were Righteous"135 despite their sins, on condition that their faith is matched by sincere repentance, a genuine commitment to obey the divine moral law, and a conscientious effort to understand God's Revealed Word with the aim of living a Christian life. ${ }^{136}$

American University in Bulgaria and University of Hamburg

135 Locke, Reasonableness, 19.

136 I started work on this article during a six-month study period as a Senior Fellow of the Maimonides Centre for Advanced Studies (MCAS) at the University of Hamburg in 2018. I am grateful to the MCAS for its generous support. Special thanks go to the MCAS Director, Giuseppe Veltri. I thank J essica GordonRoth, Paul Lodge, and Antonia LoLordo for inviting me to the 2018 J ohn Locke Workshop at Mansfield College, University of Oxford, where I gave a shorter version of this essay. I am grateful to Ruth Boeker for serving as my respondent at the 2018 Locke Workshop and to all participants in this workshop for their questions and advice. I am thankful to Raffaele Russo and Shelley Weinberg for their suggestions concerning, respectively, Locke's religious thought and his theory of personal identity. I thank Benjamin Hill and three anonymous reviewers for their feedback and recommendations. Finally, I am grateful to my home institution, the American University in Bulgaria, for its continued support of my scholarly activities. 


\section{Bibliography}

Almond, Philip C. Heaven and Hell in Enlightenment England. Cambridge: Cambridge University Press, 1994.

Anderson, David J . "Susceptibility to Punishment: A Response to Yaffe." Locke Studies 8 (2008): 101-6.

Artis, Aderemi. “Locke on Original Sin.” Locke Studies 12 (2012): 201- 19.

Ball, Bryan W. The Soul Sleepers: Christian Mortalism from Wycliffe to Priestley. Cambridge: J ames Clarke, 2008.

Boeker, Ruth. "Locke on Personal Identity: A Response to the Problems of His Predecessors." J ournal of the History of Philosophy 55, no. 3 (2017): 407- 34.

- "The Moral Dimension in Locke's Account of Persons and Personal Identity." History of Philosophy Quarterly 31, no. 3 (2014): 229- 47.

- . "The Role of Appropriation in Locke's Account of Persons and Personal Identity." Locke Studies 16 (2016): 3- 39.

Burns, Norman T. Christian Mortalism from Tyndale to Milton. Cambridge: Harvard University Press, 1972.

Crellius, Johannes. Ad librum Hugonis Grotii quem de satisfactione Christi adversus Faustum Socinum Senensem scripsit. Racoviae [Raków], 1623.

de Beer, E. S., ed. The Correspondence of J ohn Locke. 8 vols. Oxford: Clarendon Press, 1976- 1989.

Forstrom, K. Joanna S. J ohn Locke and Personal Identity: Immortality and Bodily Resurrection in 17th-Century Philosophy. London: Continuum, 2010.

Gordon-Roth, Jessica. "Locke on Personal Identity." In Stanford Encyclopedia of Philosophy, published February 11, 2019, https:// plato.stanford.edu/entries/lockepersonal-identity/.

Grotius, Hugo. Defensio fidei Catholicae de satisfactione Christi adversus Faustum Socinum. Leiden, 1617.

Harrison, John, and Peter Laslett, eds. The Library of John Locke. 2nd ed. Oxford: Clarendon Press, 1971. 
Higgins-Biddle, John C. Introduction to The Reasonableness of Christianity, as Delivered in the Scriptures by J ohn Locke, xv- cxv. Edited by J ohn C. Higgins-Biddle. Oxford: Clarendon Press, 1999.

J olley, Nicholas. Locke's Touchy Subjects: Materialism and Immortality. Oxford: Oxford University Press, 2015.

Limborch, Philipp van. Theologia Christiana. Amsterdam, 1686.

Locke, J ohn. "Adversaria Theologica 94." In J ohn Locke: Writings on Religion, edited by Victor Nuovo, 19- 33. Oxford: Oxford University Press, 2002.

—. An Essay concerning Human Understanding. Edited by Peter H. Nidditch. Oxford: Clarendon Press, 1975.

—. "Of Ethick in General." In J ohn Locke: Writings on Religion, edited by Victor Nuovo, 9- 14. Oxford: Oxford University Press, 2002.

_ . "Homo ante et post lapsum." In J ohn Locke: Writings on Religion, edited by Victor Nuovo, 231. Oxford: Oxford University Press, 2002.

—. "On the Immortality of the Soul." In An Early Draft of Locke's Essay: Together with Excerpts from His J ournals, edited by Richard I. Aaron and J ocelyn Gibb, 12123. Oxford: Clarendon Press, 1936.

—. "MS Locke c. 27, f. 101, Christianitie." In The Reasonableness of Christianity, as Delivered in the Scriptures, edited by John C. Higgins-Biddle, 198-200. Oxford: Clarendon Press, 1999.

—. "MS Locke c. 27, f. 103, Adam ante lapsum immortalis." In The Reasonableness of Christianity, as Delivered in the Scriptures, edited by J ohn C. Higgins-Biddle, 201. Oxford: Clarendon Press, 1999.

—. "MS Locke c. 27, ff. 104- 111." In The Reasonableness of Christianity, as Delivered in the Scriptures, edited by J ohn C. Higgins-Biddle, 201- 5. Oxford: Clarendon Press, 1999.

—. A Paraphrase and Notes on the Epistles of St Paul to the Galatians, 1 and 2 Corinthians, Romans, Ephesians. Edited by Arthur W. Wainwright. 2 vols. Oxford: Clarendon Press, 1987.

—. "Peccatum originale." In J ohn Locke: Writings on Religion, edited by Victor Nuovo, 229- 30. Oxford: Oxford University Press, 2002.

—. The Reasonableness of Christianity, as Delivered in the Scriptures. Edited by J ohn C. Higgins-Biddle. Oxford: Clarendon Press, 1999. 
- Reply to the Right Reverend theLord Bishop of Worcester's Answer to His Second Letter. In vol. 3 of The Works of J ohn Locke, 9 vols., 12th ed., 191-499. London, 1824.

_. "Resurrectio et quae sequuntur." In J ohn Locke: Writings on Religion, edited by Victor Nuovo, 232- 37. Oxford: Oxford University Press, 2002.

- A Second Vindication of the Reasonableness of Christianity, 27-233. In Vindications of the Reasonableness of Christianity. Edited by Victor Nuovo. Oxford: Clarendon Press, 2012.

—. "Spirit, Soul, and Body." In A Paraphrase and Notes on the Epistles of St Paul to the Galatians, 1 and 2 Corinthians, Romans, Ephesians, edited by Arthur W. Wainwright, 2:675- 78. Oxford: Clarendon Press, 1987.

— Two Treatises of Government. Edited by Peter Laslett. Cambridge: Cambridge University Press, 1988.

—_. "Voluntas." In Locke: Political Essays, edited by Mark Goldie, 321. Cambridge: Cambridge University Press, 1997.

LoLordo, Antonia. Locke's Moral Man. Oxford: Oxford University Press, 2012.

Mackie, J. L. Problems with Locke. Oxford: Clarendon Press, 1976.

Marshall, John. John Locke: Resistance, Religion and Responsibility. Cambridge: Cambridge University Press, 1994.

—. 'Locke, Socinianism, 'Socinianism,' and Unitarianism." In English Philosophy in the Age of Locke, edited by M. A. Stewart, 111- 82. Oxford: Clarendon Press, 2000.

Mortimer, Sarah. Reason and Religion in the English Revolution: The Challenge of Socinianism. Cambridge: Cambridge University Press, 2010.

Noonan, Harold W. “Locke on Personal Identity.” In J ohn Locke, An Essay concerning Human Understanding in Focus, edited by Gary Fuller, Robert Stecker, and J ohn P. Wright, 210-35. London: Routledge, 2000.

Nuovo, Victor. John Locke: The Philosopher as Christian Virtuoso. Oxford: Oxford University Press, 2017.

Rabieh, Michael S. "The Reasonableness of Locke, or the Questionableness of Christianity." The J ournal of Politics 53, no. 4 (1991): 933- 57.

Schneewind, J . B. “Locke's Moral Philosophy.” In The Cambridge Companion to Locke, edited by Vere Chappell, 199- 225. Cambridge: Cambridge University Press, 1994. 
Sell, Alan P. F. John Locke and the Eighteenth-Century Divines. Cardiff: University of Wales Press, 1997.

Simonutti, Luisa. “Locke's Biblical Hermeneutics on Bodily Resurrection." In Locke and Biblical Hermeneutics: Conscience and Scripture, edited by Luisa Simonutti, 55- 74. Cham: Springer, 2019.

Snobelen, Stephen D. "Socinianism, Heresy and John Locke's Reasonableness of Christianity." Enlightenment and Dissent 20 (2001): 88- 125.

Socinus, Faustus. “De J esu Christo Servatore.” In Fausti Socini Senensis Opera Omnia, volume 2 of Bibliotheca Fratrum Polonorum quos Unitarios vocant, 9 vols., 115- 246. Irenopoli [Amsterdam], post annum Domini 1656 [1665- 1692].

Spellman, William M. John Locke and the Problem of Depravity. Oxford: Clarendon Press, 1988.

Stillingfleet, Edward. An Answer to Mr. Locke’s Second Letter. London, 1698.

—. A Discourse in Vindication of the Doctrine of the Trinity. London, 1697.

Strawson, Galen. Locke on Personal Identity: Consciousness and Concernment. 2nd ed. Princeton: Princeton University Press, 2014.

Sugg, Richard. The Smoke of the Soul: Medicine, Physiology and Religion in Early Modern England. Basingstoke: Palgrave Macmillan, 2013.

Thiel, Udo. The Early Modern Subject: Self-Consciousness and Personal Identity from Descartes to Hume. Oxford: Oxford University Press, 2011.

—. "The Trinity and Human Personal Identity." In English Philosophy in the Age of Locke, edited by M. A. Stewart, 217-43. Oxford: Clarendon Press, 2000.

Wainwright, Arthur W. Introduction to A Paraphraseand Notes on the Epistles of St Paul to the Galatians, 1 and 2 Corinthians, Romans, Ephesians by J ohn Locke, 1:1-88. Edited by Arthur W. Wainwright. Oxford: Clarendon Press, 1987.

Wallace, Dewey D. "Socinianism, J ustification by Faith, and the Sources of J ohn Locke's The Reasonableness of Christianity." J ournal of the History of Ideas 45, no. 1(1984): 49- 66.

Weinberg, Shelley. Consciousness in Locke. Oxford: Oxford University Press, 2016.

—_. “Locke on Personal Identity.” Philosophy Compass 6, no. 6 (2011): 398-407. 
Williams, George H., ed. The Polish Brethren: Documentation of the History and Thought of Unitarianism in the Polish-Lithuanian Commonwealth and in the Diaspora 1601- 1685. 2 vols. Missoula: Scholars Press, 1980.

Woolhouse, Roger. Locke: A Biography. Cambridge: Cambridge University Press, 2007.

Wootton, David. "J ohn Locke: Socinian or Natural Law Theorist?" In Religion, Secularization and Political Thought: Thomas Hobbes to J.S. Mill, edited by J ames E. Crimmins, 39- 67. London: Routledge, 1989.

Yaffe, Gideon. "Locke on Ideas of Identity and Diversity." In The Cambridge Companion to Locke's "Essay concerning Human Understanding", edited by Lex Newman, 192230. Cambridge: Cambridge University Press, 2007.

Yolton, J ohn W. The Two Intellectual Worlds of J ohn Locke: Man, Person, and Spirits in the "Essay." Ithaca: Cornell University Press, 2004. 